\title{
Delivering impact for adolescent girls: Emerging findings from Population Council research
}

Population Council

Follow this and additional works at: https://knowledgecommons.popcouncil.org/departments_sbsr-pgy

Part of the Demography, Population, and Ecology Commons, Family, Life Course, and Society Commons, Gender and Sexuality Commons, and the International Public Health Commons How does access to this work benefit you? Let us know!

\section{Recommended Citation}

"Delivering impact for adolescent girls: Emerging findings from Population Council research," GIRL Center Synthesis Brief. New York: Population Council, 2018. 


\section{DELIVERING IMPACT FOR ADOLESCENT GIRLS}

EMERGING FINDINGS FROM POPULATION COUNCIL RESEARCH 
Nine rigorous

impact evaluations

from around the

world indicate that

empowerment

and asset-building

interventions for

adolescent girls can

improve education,

health, economic,

social capital,

gender-equitable

attitude, and violence

outcomes for girls.

\section{KEY FINDINGS}

\section{Empowerment and asset-building interventions targeting multiple levels of girls' socio-ecological environment can improve education, health, economic, social capital, gender-equitable attitude, and violence outcomes for girls.}

- In Bangladesh, Burkina Faso, Ethiopia, Liberia, and Tanzania, empowerment and asset-building interventions working on multiple levels were effective in delaying age at marriage.

- In Bangladesh, Kenya, India, Liberia, and Zambia, ${ }^{1}$ empowerment and asset-building interventions targeting the individual, household, and/or community level improved education, health, economic, social capital, and gender-equitable attitude outcomes for girls.

- Empowerment and asset-building interventions that address gender-based violence at the individual and community level had mixed impact, with reductions in violence outcomes in Bangladesh and in one of the interventions in India, and no change in Liberia.

Programs are more effective at improving outcomes for adolescent girls when cash and asset transfers to households are combined with empowerment components.

- In Kenya and Liberia, empowerment components were coupled with conditional cash transfers to households. In a multi-country evaluation in Burkina Faso, Ethiopia, and Tanzania, conditional asset transfers (e.g., goats, chickens) were given to households.

- In Kenya, the cash transfer to households had the most significant impact when girls also participated in empowerment components. The cash transfer was conditioned on girls' enrollment and regular attendance at school, and increased completion of primary school and transition to secondary school for girls in their final two years of primary school when the intervention started in Kibera (urban informal settlement) and school enrollment and numeracy in Wajir.

- In Liberia, the cash transfer was conditioned on girls' participation and had an additional impact on delaying marriage and increasing safer sexual experiences when coupled with empowerment efforts. 


\section{Promotion and integration of appropriate technologies for girls is feasible and effective.}

- In Bangladesh and Zambia, ${ }^{2}$ girls were given access to technology that is uncommon in the study communities. In Bangladesh, girls learned how to operate health technology (e.g., blood pressure machines), computers, and mobile phones. In Zambia, e-readers were distributed to girls participating in a school-based empowerment program.

- The introduction of these technologies was successful. A goal in introducing these technologies was to build girls' skills to navigate an increasingly digital world and improve outcomes for adolescent girls.

\section{Each intervention presented in this brief had a positive effect supporting its theory of change, some with evidence of impact on longer-term outcomes and others showing encouraging findings on proximal determinants of girls' empowerment.}

- Theories of change guide the intervention design and expected program impact. Many of the outcomes are expected to occur later in the adolescent's transition to adulthood-particularly for very young adolescents (e.g., leaving school, sexual debut, getting married, giving birth), while some are more immediate (e.g., self-efficacy, agency, skills, access to resources). The interventions themselves range from a period of six months' to two years' duration, and the observation of impact ranged from immediately after to two years post-intervention.

- There was evidence of positive impact on longer-term health, education, economic, and violence outcomes in multiple evaluations: delayed age at marriage in Bangladesh, Burkina Faso, Ethiopia, Guatemala, Liberia, and Tanzania; increased school enrollment in Bangladesh and Kenya (Wajir); and decreased experience of physical violence in Bangladesh, Guatemala, and India (through self-help groups).

- Other evaluations yielded encouraging findings on proximal determinants of empowerment, such as improved numeracy in Bangladesh and Kenya (Wajir), and improved literacy in Zambia; improved sexual and reproductive health knowledge in Bangladesh, Liberia, Kenya (Kibera), and Mexico; and increases in desired age for marriage in Kenya (Wajir) and Mexico and gender-equitable attitudes in India and Kenya (Wajir).

\footnotetext{
1 There are two studies from Zambia included in this brief; here we refer to the GirlsRead! intervention. GirlsRead! was funded in part by a grant from the United States Department of State as part of the DREAMS Innovation Challenge, managed by JSI Research \& Training Institute, Inc. (JSI).

2 Refers to GirlsRead!
} 


\section{BACKGROUND}

The largest generation of 10-19 year olds $\left(\sim 1.2\right.$ billion $\left.^{3}\right)$ presents the world with an unprecedented potential to further spur social and economic progress. With the majority of adolescents living in low- and middle-income countries (LMICs), identifying the factors and programs that prevent adolescents from falling into or remaining in poverty is more pressing than ever.

Adolescence is a critical period in the transition from childhood to adulthood. During this period of rapid growth and development, adolescents acquire important health and social knowledge, shape their beliefs and attitudes, and establish lifelong behaviors. Globally, girls face unique challenges during adolescence, with an elevated risk of school dropout, child marriage and pregnancy, sexually transmitted disease and HIV acquisition, and experience of violence. A growing interest in adolescent girls has placed them front and center in many global health and development policies and programs. Despite the numerous global commitments to invest in improving the lives of adolescent girls, there is limited understanding of what package of interventions can deliver the best outcomes. Often, investments designed to change the lives of girls are thinly spread across development sectors, are short-term, and are not evidence-based.

The Population Council is building one of the world's largest bodies of research on programs to improve the lives of adolescents, especially girls. For the past two decades, the Council has been identifying best practices, refining the critical elements of girlcentered programs, and using rigorous evidence to help decisionmakers allocate scarce resources to the most effective programs. The Council's adolescent girls research portfolio is also supporting decisionmakers to formulate the most effective evidencebased policies to improve girls' lives and meet national development goals.

This brief summarizes key findings from nine rigorous evaluations of empowerment and asset-building interventions for adolescent girls. We present emerging findings, consider the implications of these findings for programs and investments, and document future research questions to close evidence gaps. Drawing on recent findings from over 50,000 individuals from Latin America, sub-Saharan Africa, and South Asia, this brief synthesizes findings from the Council's research portfolio on adolescent girls. Each intervention/ evaluation has been assigned a number that will be used throughout the brief and in the companion tables.

Collectively, these evaluations provide evidence on whether a particular intervention, or a package of interventions, had an impact for adolescent girls within the areas of education, health (e.g., sexual and reproductive health), economic empowerment, social capital, gender-equitable attitudes, and violence. Some of the findings have already been published in peer-reviewed journals, while other results are preliminary and have yet to be peer reviewed. Five of the nine evaluations also consider costs and a cost assessment per girl served, which is an important consideration for replicating and scaling these approaches.

${ }^{3}$ UNICEF. 2011. The State of the World's Children 2011. Adolescence: An Age of Opportunity. New York: UNICEF. 


\section{Burkina Faso}

6A
India
Bangladesh

5
8

Liberia

\section{Ethiopia}

$6 B$

\section{A}

$4 B$ Kenya

6C

Tanzania
39

Zambia

This brief summarizes key findings from nine rigorous evaluations of empowerment and asset-building interventions drawn from the Population Council's research portfolio on adolescent girls (see map above and Table 1 on page 7).

(1) Abriendo Futuros/Opening Futures (Mexico/rural)

2 Abriendo Oportunidades/Opening Opportunities (Guatemala/rural)

(3) Adolescent Girls Empowerment Program (AGEP) (Zambia/rural and urban)

4A Adolescent Girls Initiative Kenya (AGI-K) (Kenya: Kibera/urban informal $[\mathrm{A}]$ and Wajir/rural [B])

5 Bangladeshi Association for Life Skills, Income, and Knowledge for Adolescents (BALIKA) (Bangladesh/rural)
Building an Evidence Base to Delay Marriage in Sub-Saharan Africa (Burkina Faso/rural [A], Ethiopia/rural [B], Tanzania/rural [C])

7A Do Kadam Barabari Ki Ore/Two Steps 7B Towards Equality (India/rural: Male youth groups [A], Self-help groups [B], Locally elected reps [C], Frontline workers [D]) 7D

8 Girl Empower (Liberia/rural)

9 GirlsRead! (Zambia/rural and urban) 


\section{INTERVENTION APPROACH}

The interventions presented in this brief were designed based on careful context analysis, taking into account available data, existing policies and programs, and community norms (see Annex: Overview of Interventions and Evaluations). There are several design, delivery, and content features that are common across the interventions, including:

- Girl groups were formulated in safe spaces

- Programs were delivered by paid female mentors

- Groups were organized by segment: by age groups, marital status, and schooling status

- The groups were guided by curricula that included consideration of gender, power dynamics, and economic empowerment (See Table 1: Program Curriculum for information on the curricula used, such as topics covered and learning modalities)

- A learner-centered interactive pedagogy was used

- Referrals were provided to help girls access additional services in their communities

\section{EVALUATION DESIGN}

The evaluations featured in this brief were conducted between 2010 and the present, with additional rounds of data collection planned in a few of the evaluations. See Annex for details of the evaluation designs and analysis methods used in the primary evaluations and sub-studies.

Of the nine evaluations:

- Six studies $23 \sqrt{4} 589$ were randomized evaluations

- One study 7 included randomized sub-studies 7 A $7 B$

- The remaining evaluations used quasi-experimental or pre-post designs 
TABLE 1. PROGRAM CURRICULUM

$\begin{aligned} & \text { Abriendo } \\ & \text { Futuros } \\ & \text { (Mexico/rural) }\end{aligned}$
$\begin{aligned} & \text { Broad themes covered include: sexual and reproductive health education, building self-esteem } \\ & \text { leadership development, empowerment and autonomy, personal hygiene and care, girl's and } \\ & \text { women's rights, gender-based violence, nutrition and healthy living, and financial literacy. }\end{aligned}$

$\begin{array}{ll}\text { Abriendo } & \text { Curricular guide contains tools and exercises for sessions with girls and mentors based on three } \\ \text { transversal axes: human rights, gender perspective, and interculturality and relevance. }\end{array}$

(Guatemala/

rural)

$\begin{aligned} & \text { AGEP } \\ & \text { (Zambia/ }\end{aligned}$
$\begin{aligned} & \text { (Zural and urban) } \\ & \text { reproductive health, life skills, HIV and AIDS, sexually transmitted infections, gender and gender- } \\ & \text { based violence, leadership, human rights, and financial education. Health and life skills and } \\ & \text { financial education curriculum are integrated rather than occurring one after the other. Nutrition } \\ & \text { curriculum for subset of girls. }\end{aligned}$

AGI-K

(Kenya)
Kibera/

urban informal
Girls grouped into 11-12 and 13-15-year-old groups; health, life skills, and nutrition curriculum delivered by a mentor; financial education curriculum focused on steps for saving and earning money, talking about money, and reflecting on good money management.

Girls grouped into 11-12 and 13-14-year-old groups; health, life skills, and nutrition curriculum delivered by a mentor with assistance from pre-recorded audio sessions; financial education curriculum focused on steps for saving and earning money, talking about money, and reflecting on good money management.
BALIKA
(Bangladesh/
Girls group formed around schooling status; basic life skills curriculum delivered across the interventions in addition to intervention-specific curriculum. All girls given basic sexual and reproductive health information. Topics addressed in 44 hours included knowing yourself and others, creative thinking, decision-making, learning how to say no, learning to compromise, physical and emotional changes in adolescence, menstrual hygiene, food and nutrition, reproductive health, HIV/AIDS, child marriage, and family planning.

\begin{tabular}{|c|c|c|}
\hline \multirow{3}{*}{$\begin{array}{l}\text { Building } \\
\text { Evidence to } \\
\text { Delay } \\
\text { Marriage }\end{array}$} & $\begin{array}{l}\text { Burkina } \\
\text { Faso/rural }\end{array}$ & \multirow{3}{*}{$\begin{array}{l}\text { Curriculum used for community conversations arm focused on team building, active listening, } \\
\text { basic information on child marriage, social capital analysis, power relations, planning and action } \\
\text { plans, follow-up, and reporting. }\end{array}$} \\
\hline & $\begin{array}{l}\text { Ethiopia/ } \\
\text { rural }\end{array}$ & \\
\hline & $\begin{array}{l}\text { Tanzania/ } \\
\text { rural }\end{array}$ & \\
\hline \multirow{4}{*}{$\begin{array}{l}\text { Do Kadam } \\
\text { Barabari } \\
\text { Ki Ore } \\
\text { (India/rural) }\end{array}$} & $\begin{array}{l}\text { Male youth } \\
\text { clubs }\end{array}$ & $\begin{array}{l}\text { Topics include: gender discrimination, notions of masculinity, and violence against women and } \\
\text { girls. }\end{array}$ \\
\hline & $\begin{array}{l}\text { Self-help } \\
\text { groups }\end{array}$ & $\begin{array}{l}\text { Gender transformative education sessions on social issues such as violence, dowry, early } \\
\text { marriage, etc., including sessions on microfinance issues, credit, savings, loans and other } \\
\text { entitlements. }\end{array}$ \\
\hline & $\begin{array}{l}\text { Locally } \\
\text { elected } \\
\text { reps }\end{array}$ & $\begin{array}{l}\text { Sensitize locally elected representatives and build their capacity to address violence against } \\
\text { women and girls and alcohol abuse. }\end{array}$ \\
\hline & $\begin{array}{l}\text { Frontline } \\
\text { workers }\end{array}$ & $\begin{array}{l}\text { Sensitize frontline workers on women's rights and the unacceptability of marital violence and } \\
\text { inform them about services available for women in distress. }\end{array}$ \\
\hline $\begin{array}{l}\text { Girl Empower } \\
\text { (Liberia/rural) }\end{array}$ & & $\begin{array}{l}\text { Life skills curriculum consisting of: sense of self, feelings and emotions, social networks, } \\
\text { protection and safety, financial literacy, reproductive health, leadership and empowerment, } \\
\text { setting life goals. [Girl Empower + only: a participation incentive payment for the girls' } \\
\text { attendance in the program sessions, paid to their parents (conditional cash transfer)]. }\end{array}$ \\
\hline $\begin{array}{l}\text { GirlsRead! } \\
\text { (Zambia/urban } \\
\text { and rural) }\end{array}$ & & $\begin{array}{l}\text { Empowerment curriculum that covers rights, respect, and responsibilities; gender norms and } \\
\text { attitudes; gender in society; sexual harassment, sexual coercion, and rape; prevention of HIV; } \\
\text { pregnancy and contraception; communication skills; valuing oneself; decisionmaking; financial } \\
\text { education; leadership; and advocacy. }\end{array}$ \\
\hline
\end{tabular}




\section{KEY FINDINGS}

Findings from each of the evaluations, including completed analyses from the peer-reviewed literature as well as preliminary analyses emerging from more recent evaluations, are included in Table 2: Intervention Impacts (education, sexual and reproductive health, economic, and social capital outcomes) and Table 3: Impact on Gender-Equitable Attitudes and Violence Against Girls. Key findings across the nine evaluations are further described below. ${ }^{4}$

\section{Empowerment and asset-building interventions targeting multiple levels of girls' socio-ecological environment can improve education, health, economic, social capital, gender-equitable attitude, and violence outcomes for girls.}

Empowerment and asset-building interventions in Bangladesh 5, Burkina Faso 6A, Ethiopia 68, Liberia 8 , and Tanzania 60 were directed toward multiple levels of society, including specific activities for community members in addition to those geared toward girls. In these settings, they were effective in delaying age at marriage. Results from Bangladesh (5) show that programs that educate girls, teach them about their rights, and build skills for modern livelihoods can reduce the likelihood of child marriage by up to one-third and produce better health, educational, economic, and social outcomes for girls. In Burkina Faso $6 \mathrm{~A}$, girls aged 15 to 17 residing in the community-dialogue arm had over two-thirds less risk of being married compared to those in the control site.

In Burkina Faso 6A, Ethiopia 6B, and Tanzania 6C, the interventions were designed to overcome household economic constraints through asset transfers and school materials and to address social norms around child marriage through community dialogue. In Ethiopia, at endline younger girls living in the communitydialogue and education-promotion sites were less likely to be married, and older girls living in sites where households received cash transfers were less likely to be married compared to their counterparts at baseline. In Tanzania, the risk of marriage was also reduced through addressing household constraints via asset transfer.

In Liberia, the evaluation of Girl Empower 8 showed a statistically significant impact on a sexual experience and marriage index. The Girl Empower + $(\mathrm{GE}+)$ variation included a participation incentive payment paid to parents for the girls' attendance in the program sessions (conditional cash transfer). Cash transfers to caregivers tied to girls' program attendance enhanced the effect by $50 \%$ of Girl Empower 8 on delaying child marriage and increasing the safety of girls' sexual encounters.

In addition to delaying marriage, many of the interventions operating at multiple levels also improved education, health, economic, social capital, and gender-equitable attitude outcomes for girls, and the findings on violence were mixed. In Zambia, the evaluation of GirlsRead! 9 shows the e-reader arm increased basic literacy skills, and analysis of its effect on other indicators is underway. Immediately after the intervention in Kenya, there were increases in education grade attainment and school progression $4 \mathrm{~A}$ and numeracy and school enrollment $4 \mathrm{~B}$, self-efficacy ${ }^{4 A} \mathrm{AB}$, sexual and reproductive health knowledge $4 \mathrm{~A}$, financial literacy and savings $4 \mathrm{~A} \mathrm{AB}$, and gender-equitable attitudes $4 \mathrm{~B}$.

\footnotetext{
4 Some of the evaluations will include additional rounds of data collection, and more time is needed-given data-collection timeline and young ages of respondents - to expect to see change on long-term indicators. In Kenya, for example, AGI-K 4 will measure long-term impact in 2019, two years after the intervention ended. While the midline collected information on marriage and pregnancy, we would not realistically expect to see change on these indicators until the endline, which will occur two years post intervention completion.
} 
${ }^{1}$ Results are preliminary; not peer reviewed. $\quad{ }^{2}$ Findings published in peer-reviewed journals. $\quad{ }^{3}$ Published in technical report.

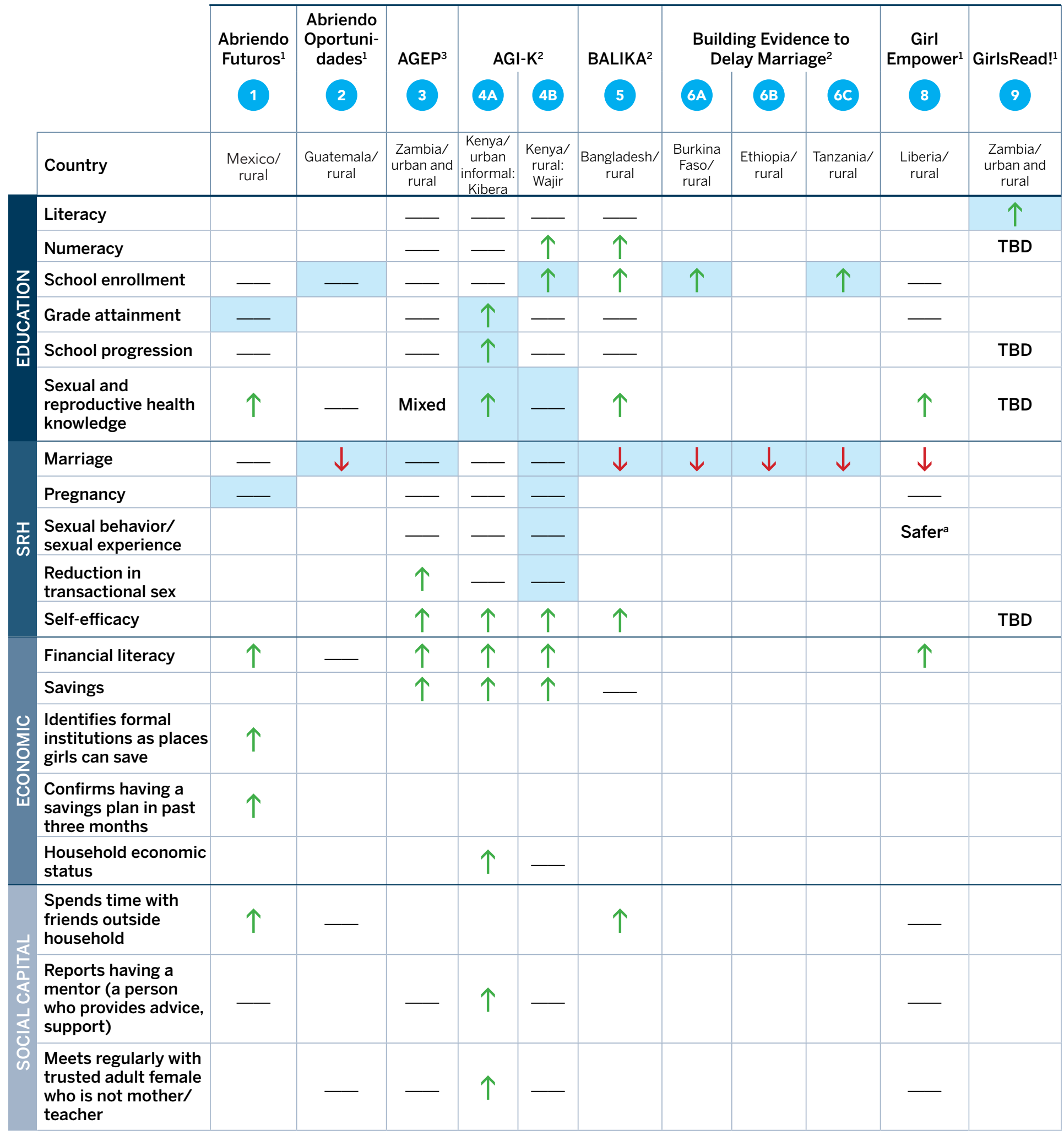

$\uparrow$ Statistically significant positive differences in outcomes between the treatment and comparison groups.

$\downarrow$ Statistically significant negative differences in outcomes between the treatment and comparison groups.

- No statistically significant difference.

Blank space $=$ No data available or not reported.
TBD $=$ Results forthcoming .

Blue shading = primary study outcome(s)

a Safer sex means delayed sexual debut, fewer sexual partners, and more consistent condom use.

Literacy measured as passed story questions and was significant for the e-reader arm but not for safe spaces arm.
Sexual and reproductive health ( $\mathrm{SRH}$ ) knowledge includes measures of: general SRH knowledge, FP knowledge, puberty and development knowledge, STI knowledge, HIV/AIDS knowledge, pregnancy knowledge.

Marriage refers to age at marriage and marital status. Self-efficacy includes condom use and help seeking self-efficacy. 
In India, three of the four intervention projects-those focused on boys $7 \mathbf{A}$, self-help groups $7 \mathbf{B}$, and elected representatives $7 c$-changed the gender-equitable attitudes of the target populations.

Interventions that addressed gender-based violence at the individual and community level had mixed impact on the experience and perpetration of violence. There were reductions in harassment in Bangladesh, and in the experience of physical violence in the self-help groups in India $7 \mathrm{~B}$. However, there was no change in the experience of sexual violence in the self-help and locally elected representatives groups 78 (7), and no change in experience of sexual violence in Liberia $\mathbf{8}$.

Some of the interventions featured in this brief-those in Guatemala 2 2 , Mexico (1), and Zambia 3 -operated exclusively at the individual level. Efforts were made to garner community support for the program at the outset, through households and community members who were not direct beneficiaries of program activities. The evaluations yielded important findings, but the interventions had mixed results on their primary outcomes. For example, the evaluation of Abriendo Futuros 1 in Mexico shows statistically significant increases on financial literacy and sexual and reproductive health knowledge but no change in pregnancy. In Guatemala, the evaluation of Abriendo Oportunidades 2 shows that girls in the treatment communities were 5.6 times less likely to report being victims of a violent incident at home relative to girls in control communities. However, there were no statistically significant differences between treatment and control girls on school enrollment.

The evaluation of AGEP 3 in Zambia shows a positive effect on financial literacy and savings, sexual and reproductive health knowledge and self-esteem, and reductions in transactional sex. The program did not, however, have an effect on sexual behavior among sexually active girls. Overall, participation in AGEP 3 did not delay the timing of pregnancies or marriages for girls in the program arms. However, for a select group of girls who actively participated, the program had a positive impact on the timing of marriage and pregnancy.

\section{The impact of interventions for younger girls was especially pronounced.}

The majority of interventions were focused on younger adolescents ( $\leq 14$ years), and some of those also included older adolescents. In most cases, empowerment and asset-building interventions had a more pronounced effect on younger girls and a narrower age range of girls.

Drawing on global data on the importance of investing in very young adolescents, all of the interventions recognized the need to include very young adolescents ( $\leq 14$ years) among their target populations in order to influence their life trajectories from an early age. In some cases, younger adolescents were exclusively targeted in the intervention: 11-14-year-olds 48; and 13-14-year-olds 8. In other interventions, younger girls were included in addition to older adolescents: 11-17-year-olds 1 ; 12-17-year-olds 2 ; 10-19-year-olds 3 ; 11-15-year-olds 44; 12-18-years-old 5; 12-17-year-olds 6 ; and grade 7 girls, ranging in age from $10-19$ (with $90 \% \leq 14$ years) 9 .

In the majority of evaluations with younger and older adolescents, analyses were stratified by age to examine the differential effects on younger and older adolescents. Interventions with a younger and narrower age range were particularly effective in demonstrating an impact on education, sexual experience, marriage, and economic outcomes for this age group. For example, four had positive effects on education, self-efficacy, social capital, sexual and reproductive health knowledge, and financial literacy and savings. In Liberia 8 , there was improved safety of sexual experiences and delayed 


\section{TABLE 3: IMPACT ON GENDER-EQUITABLE ATTITUDES AND VIOLENCE AGAINST GIRLS}

${ }^{1}$ Results are preliminary; not peer reviewed. $\quad{ }^{2}$ Findings published in peer-reviewed journals.

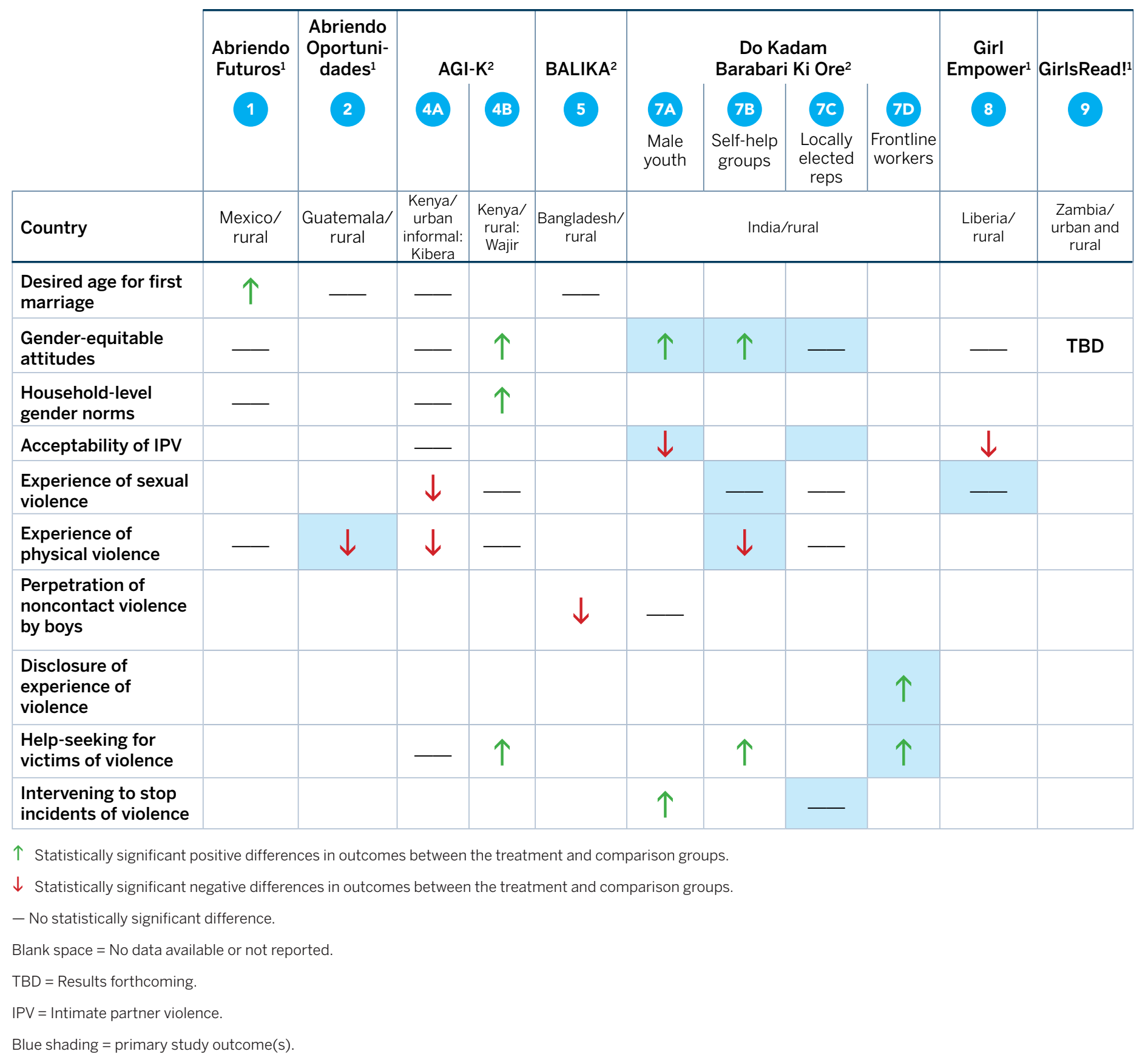


marriage. In Tanzania 6C, girls 12 to 14 residing in the comprehensive site had two-thirds less risk of being married compared to girls in the control site. For the older group of girls (15-17-year-olds) in Tanzania, there were no statistically significant differences between those receiving the full model and controls.

The only exception deviating from a pattern of more pronounced outcomes for younger girls is AGEP 3 , where younger girls were more likely to participate in the program, but the effect size for increase in sexual and reproductive health knowledge was strongerfor older girls than for younger girls.

\section{Programs are more effective at improving outcomes for adolescent girls when cash and asset transfers to households are combined with empowerment components.}

Conditional cash transfers to households were coupled with empowerment components in Kenya (4) and Liberia 8. In a multi-country evaluation in Burkina Faso, Ethiopia, and Tanzania 6 households received conditional asset transfers (e.g., chickens, goats). The evidence from these countries reinforces the theory that addressing empowerment for adolescent girls through a multisectoral approach leads to larger impact, and that programs are more effective at improving education, health, and economic outcomes when social, health, and asset-building for girls is supplemented with household economic incentives ("cash plus").

In Kenya, all girls whether in or out of school were eligible for household cash transfer, conditional on school enrollment and regular attendance at school. The four components of the conditional transfer included: (1) fees to be paid directly to the school at the start of each term for primary school ( US\$7) and secondary school ( US\$60); (2) a cash transfer paid to the head of the household twice per term ( US $\$ 11$ $(4 A$ and $\sim$ US $\$ 15$ (4B); (3) schooling kits given directly to girls at the start of each term containing sanitary towels, underpants, and basic school supplies; and 4 an incentive paid directly to the school each term based on the number of girls enrolled in the cash transfer program ( US $\$ 5 /$ girl). The conditional transfers were effective, but the impact was dependent on the baseline status of girls' education in each site. In Kibera 44 , the conditional cash transfer improved completion of primary school (from $84 \%$ to $91 \%$ ) and the transition to secondary school (from $81 \%$ to $89 \%$ ) for girls who were in the final two years of primary school at the start of the intervention. In Wajir 48, where about a quarter of girls were out of school at baseline, the education conditional cash transfer had a large impact on primary school enrollment and retention, increasing enrollment to $95 \%$.

The Girl Empower (GE) empowerment program in Liberia (4B included the Girl Empower + (GE+) variation, where caregivers of program participants received a payment of US $\$ 1.25$ for each of the 32 regular sessions that the adolescent girl attended, for a maximum of US\$40. GE delayed child marriage and increased the safety of girls' sexual encounters. Cash transfers to caregivers tied to girls' program attendance increased effect sizes of GE on marriage and sexual experience by $50 \%$.

However, in a multi-country evaluation in Burkina Faso 6 A , Ethiopia 68 , and Tanzania 68 , the conditional asset transfer was given independent of empowerment components for girls and consisted of livestock (a goat in Burkina Faso and Tanzania; chickens in Ethiopia), provided on the condition that girls remain unmarried and in school during the pilot program. The conditional asset arm was effective at delaying marriage among older girls in Ethiopia 6 B and Tanzania $6 C$. In Burkina Faso $6 \mathrm{~A}$ and Tanzania 60 , the goat was awarded once at the end of the intervention period (just over two years), while school supplies were given yearly. In Ethiopia 6B, chickens were provided on a yearly basis and school supplies were provided twice per year. Girls 15 to 17 residing in the conditional asset transfer site in Tanzania $6 c$ had roughly half 
the risk of being married compared to girls in the control site. More frequent provision of lower-cost assets seems to have had the effect of sustaining interest and commitment to the program. Public, communitywide award of the commodities was used as a way to bring visibility to the status of girls in the project communities. The frequency of these events may have served to encourage girls and their parents to abide by the conditions.

\section{Promotion and integration of appropriate technologies for girls is feasible and effective.}

In Bangladesh 5 and Zambia 9, empowerment group participants were given access to technology that is rare or even unheard of in the study communities. A goal in introducing these technologies was to build

girls' skills to navigate an increasingly digital world, and improve outcomes for adolescent girls. Availability of such technology helps bridge the digital divide and provides digital learning material via e-readers, computers, tablets, mobile phones, and blood pressure machines. These interventions were thoughtful in their selection of appropriate technologies for girls, and while technology such as e-readers were taken home 9 , they were also integrated within a safe spaces approach that included collaborative reading activities and reading-related games.

In the case of Zambia 9, e-readers were introduced to respond to a lack of books and a lack of diverse content and reading levels. Girls participating in the e-reader + empowerment groups received their own e-readers and were allowed to take them home. Because e-readers were kept by girls for the duration of the program-and were not simply used in school or libraries - girls were visibly and publicly demonstrating their new reading behavior and their comfort with technology. At the end of the intervention, less than $2.5 \%$ of the e-readers had been lost, broken, or stolen. Among girls who attended at least 16 of the 19 sessions, two literacy benchmarks were 8 to 16 percentage points higher at endline in the e-reader arm than in the control arm. The intervention controlled for baseline differences and selectivity of those more likely to participate.

Similarly, the use of multiple forms of technology in the safe spaces in Bangladesh 5 was feasible across the 72 intervention communities. Girls in the livelihood skills arm learned how to operate health technology (e.g., blood pressure machines), computers, and mobile phones. While these forms of technology were new to girls within the community, they were effective in building girls' confidence and elevating their profiles within the community. Moreover, the evaluation showed that building girls' skills for modern livelihoods reduced child marriage by roughly one-quarter.

\section{Each intervention presented in this brief had a positive effect supporting its theory of change, some with evidence of impact on longer-term outcomes and others showing encouraging findings on proximal determinants of girls' empowerment.}

Theories of change guide the intervention design and expected program impact. Many of the outcomes are expected to occur later in the adolescent's transition to adulthood-particularly for very young adolescents (leaving school, sexual debut, getting married, giving birth), while some are more immediate (self-efficacy, agency, skills, access to resources). The interventions presented in this brief range from six months' (9) to more than two years' duration (6), and observation of impact on girls outcomes ranged from immediate (1 4 5 6 7C 7D to one 8 to two years post-intervention 3). In Zambia 9), literacy was assessed immediately after the intervention ended and again 4-7 months later along with other outcome indicators. 
There was evidence of positive impact on longer-term health, education, economic, and violence outcomes in multiple evaluations. In Bangladesh 5, Burkina Faso 6A, Ethiopia 6B, Guatemala 2 , Liberia 8 and Tanzania 66, there was a delayed age at marriage. In Guatemala 2 , girls in treatment communities were 3.4 percentage points less likely to report being married, in a union, separated, or divorced, compared to girls in control communities. However, marriage remained unchanged in Mexico (1. Kenya 4. and Zambia 3. One should be cautious in interpreting these results for Kenya given the young age of the sample and the immediacy of results post-intervention. The forthcoming data collected two years post-intervention should provide important information on the impact of the intervention on marriage and pregnancy in the long-term.

Other evaluations yielded encouraging findings on proximal determinants of girls' empowerment. For example, increases in sexual and reproductive health $(\mathrm{SRH})$ knowledge were observed in Bangladesh ${ }^{5}$, Kibera, Kenya 4A, Liberia 8 , and Mexico (1); there were mixed results on SRH knowledge in Zambia 3 with increases for older girls but not for younger girls; and SRH knowledge remained unchanged in Guatemala 2 and Wajir, Kenya 4B. Increases in the age of desired marriage, a more medium-term indicator for adolescent well-being, were observed in Wajir, Kenya $4 \mathrm{~B}$ and Mexico 1 and remained unchanged in Bangladesh 5, Guatemala 2 , and Kibera, Kenya 4A.

Improvements in educational outcomes, such as school enrollment, were observed in Bangladesh (5), Burkina Faso 6A, Wajir, Kenya 48, and Tanzania 60 and remained unchanged in Guatemala 2 , Kibera, Kenya 4A, Liberia 8, Mexico (1), and Zambia 3. Grade attainment and school progression could also be considered more long-term education outcomes, and the only site with improvement in these indicators was Kibera, Kenya ${ }^{4 A}$, while grade attainment and school progression remained stagnant in Bangladesh 5. Wajir, Kenya 4B, Liberia 8, Mexico (1), and Zambia 3. Literacy and numeracy were measured as proximal determinants of long-term educational attainment. These more medium-term indicators improved in Bangladesh (numeracy, 5), Wajir, Kenya (numeracy, 48), and Zambia (literacy, (9). In Zambia, the intent to treat analysis showed significant improvements in the ability of girls in the e-reader arm to pass story questions (correctly answer questions about a story) compared with girls in the control arm. In the treatment on the treated analysis, the more sessions girls attended, the larger the effect on two literacy indicators. Numeracy remained unchanged in Kibera, Kenya ${ }^{4 A}$ and Zambia 3 , and literacy remained unchanged in Bangladesh (5, Kenya (4), and Zambia 3.

Changes in experience of violence are unlikely to be observed in the short-term. Reductions in experience of physical violence were observed in Guatemala 2 and in one of the interventions in India (self-help groups (78). Physical violence remained unchanged in Wajir, Kenya (48), Mexico 1 , and in one of the interventions in India (locally elected representatives, $7 c$ ). Experience of sexual violence remained unchanged in two of the interventions in India (self-help groups $7 \mathrm{~B}$ and locally elected representatives (7)); in Wajir, Kenya (48; and in Liberia 8. In Bangladesh (5), there was a reduction in harassment and non-contact violence perpetrated by boys.

While not all of the evaluations measured experience of violence, many of them included indicators such as gender-equitable attitudes, which can be seen as proximal to adolescent well-being. These attitudes improved in Wajir, Kenya $4 \mathrm{~B}$ and two of the interventions in India (boys and young men, $7 \mathrm{~A}$ and self-help groups (7B), but remained unchanged in Kibera, Kenya (4B, Mexico (1), and in one of the interventions in India (elected representatives (7)). In Liberia 8 , attitudes toward interpersonal violence improved significantly, but gender-equitable attitudes did not change. 


\section{COST PER PERSON SERVED}

In addition to measuring impact on the intended outcomes, several of the evaluations $3 / 405$ calculated the cost of implementing the interventions. These findings are informative given the dearth of costed studies on many of the outcomes for adolescents in LMICs. The majority of cost studies of actual implemented programs focus on a single or narrow set of outcomes. ${ }^{5}$ Other existing studies tend to focus on the economic costs of not intervening with adolescent girls and the impact on individuals, households, and society. ${ }^{6}$

Some of the interventions featured in this brief reached community members rather than girls alone; therefore, costs are listed per person served, recognizing that for community members this may mean estimating the magnitude of the population reached. Costs were measured slightly differently in each evaluation, but for the most part it was the cost to implement the activities and support girls. As expected, costs varied depending on country and intervention.

The cost analysis in Zambia 3 calculated the implementation cost per beneficiary, which totaled $\$ 394$ per girl for the safe space groups, an additional \$293 per girl for the health voucher, and an additional \$551 per girl for the savings account (adjusted for inflation to 2016 \$US). A large component of the safe space group costs were staff costs of implementing and monitoring the groups and the per diems that were paid to mentors over the two years of the program. The additional costs associated with the bank account were largely related to transporting all the girls to the bank branches to receive an introduction and to open

TABLE 4: INCREMENTAL AND INTERVENTION ANNUAL PACKAGE COSTS IN KENYA (AGI-K)

\begin{tabular}{lccccc} 
& \multicolumn{2}{c}{ Kibera } & & \multicolumn{2}{c}{ Wajir } \\
\cline { 2 - 3 } & $\begin{array}{l}\text { Incremental } \\
\text { annual cost } \\
\text { (per beneficiary) }\end{array}$ & $\begin{array}{l}\text { Total package } \\
\text { annual cost } \\
\text { (per beneficiary) }\end{array}$ & & $\begin{array}{l}\text { Incremental } \\
\text { annual cost } \\
\text { (per beneficiary) }\end{array}$ & $\begin{array}{l}\text { Total package } \\
\text { annual cost } \\
\text { (per beneficiary) }\end{array}$ \\
$\begin{array}{l}\text { Violence prevention } \\
\text { only }\end{array}$ & $\$ 33$ & $\$ 33$ & $\$ 116$ & $\$ 115$ \\
\hline $\begin{array}{l}\text { V+ Education } \\
\text { V+ E + Health }\end{array}$ & $\$ 242$ & $\$ 275$ & $\$ 373$ & $\$ 215$ & $\$ 332$ \\
\hline $\begin{array}{l}\text { V+ E + Health }+ \\
\text { Wealth Creation }\end{array}$ & $\$ 39$ & $\$ 142$ & & $\$ 250$ & $\$ 581$ \\
\hline
\end{tabular}

Source: Austrian, Soler-Hampejsek, Mumah, et al. 2018.

5 See, for example, the Department of Health and Human Services' (Zaveri et al. 2017) summary of per capita costs of US teen pregnancy prevention programs, which are higher than the per capita costs of the interventions featured in this brief, or the Guttmacher Institute (2016) example of the cost of providing contraception to 15-19-year-olds with unmet need in LMICs.

${ }^{6}$ See, for example, Azevedo et al. 2012 for the costs of not intervening in teen motherhood, or Wodon et. al 2017 on the economic costs of child marriage on: (1) fertility and population growth; (2) health, nutrition, and violence; (3) educational attainment and learning; (4) labor force participation and earnings; and (5) participation, decisionmaking, and investments. 
TABLE 5: COST PER GIRL ENROLLED IN BANGLADESH (BALIKA)

Total cost

Girls enrolled in the program

Cost per girl enrolled

\begin{tabular}{llll}
\hline Education & $\$ 513,450$ & 3,180 & $\$ 161$ \\
\hline Gender & $\$ 421,917$ & 3,269 & $\$ 129$ \\
\hline Livelihood & $\$ 522,290$ & 3,240 & $\$ 170$ \\
\hline TOTAL & $\$ 1,457,657$ & 9,689 & $\$ 154$ (average)
\end{tabular}

Source: Amin, Saha, and Ahmed 2018.

TABLE 6: COST PER GIRL/PERSON SERVED PER YEAR, BY MODEL AND COUNTRY IN SUB-SAHARAN AFRICA

\begin{tabular}{lccc} 
& $\begin{array}{l}\text { Burkina Faso } \\
(\mathbf{n}=\mathbf{3}, \mathbf{2 3 5})\end{array}$ & $\begin{array}{c}\text { Ethiopia } \\
(\mathbf{n}=\mathbf{5}, \mathbf{1 6 7})\end{array}$ & $\begin{array}{c}\text { Tanzania } \\
(\mathbf{n}=\mathbf{4 , 1 5 4 )}\end{array}$ \\
\hline Community dialogue & $\$ 12$ & $\$ 20$ & $\$ 9$ \\
\hline School promotion & $\$ 13$ & $\$ 20$ & $\$ 18$ \\
\hline Conditional asset transfer & $\$ 33$ & $\$ 32$ & $\$ 107$ \\
\hline Comprehensive model & $\$ 60$ & $\$ 29$ & $\$ 117$ \\
\hline
\end{tabular}

Source: Erulkar, Medhin, and Weissman 2017.

the bank accounts. It is expected that a scaled-up version of the program would be less expensive, as approximately $20 \%$ of the costs were start-up costs, as well as added expenses incurred to implement the program in the context of a randomized controlled trial.

Given the multiple components within the intervention approach in Kenya 4, incremental costs were used to report on costs of each component, as well as the cost of the total intervention package per beneficiary.

In Bangladesh 5, the costs for each arm (education, gender, and livelihoods) were calculated separately. Of the total cost, an estimated 54\% was incurred in the implementation phase and the remainder in the preparatory phase. Total cost estimated was \$154 per girl. While the education and livelihood arms were similar, the cost associated with the gender arm was lower.

In all countries included in the evaluation of Building Evidence to Delay Marriage (6), the costs of intervening were consistent with the costs presented in the Guttmacher Institute (2016) estimate of providing contraception to 15-19-year-olds in LMICs. In the evaluation, the community dialogue and school promotion cost roughly the same: from $\$ 9$ to $\$ 20$ per community member served for community dialogue and from $\$ 13$ to $\$ 20$ per girl served with school supplies. The conditional asset transfer and the comprehensive models were the most costly to implement, likely given the cost of procuring, storing, and transporting livestock. 
TABLE 7: COST PER TARGET POPULATION REACHED IN BIHAR, INDIA (DO KADAM BARABARI KI ORE)

Total cost Target population $\quad$ Cost per unit

\begin{tabular}{lccc}
\hline Male youth clubs & $\$ 140,956$ & 15 clubs & $\$ 9,397$ \\
\hline Self-help groups & $\$ 218,767$ & 28 villages & $\$ 7,813$ \\
\hline Locally elected representatives & $\$ 90,416$ & 9 villages & $\$ 10,046$ \\
\hline Frontline workers & $\$ 104,477$ & 10 villages & $\$ 10,448$ \\
\hline TOTAL & $\$ 554,616$ & &
\end{tabular}

Source: Weissman 2017

The full model in Ethiopia $6 \mathrm{~B}$ was cheaper to implement ( $\$ 29$ per girl per year) compared to the conditional asset transfer of two chickens per girl per year. Further examination of costing data suggested that fewer girls in the comprehensive arm received chickens at all rounds of the study, reflecting their failure to meet the project's criteria.

In the four interventions in India 7 , the program-costing data (not including overall oversight of the program) were presented as a cost per target population reached, recognizing the population as clubs or villages rather than a set number of individuals.

Across Kibera, Kenya $4 A$ and 6 , the community-only aspect was the least expensive to implement, and the conditional cash or asset transfer was the most costly. Overall, the interventions were more expensive to implement in Wajir, Kenya $4 \mathrm{~B}$, largely due to the challenges in working in such a vast terrain with poor infrastructure vis-à-vis roads, electricity, and security.

Despite the different methods of measuring cost per person, these evaluations include important costing information that can shed light on the resources needed for future planning and for scaling up some of these interventions. While there is limited evidence of costs of other empowerment, girl-centered approaches, the costs of the interventions described in this brief are comparable to or less than the costs included in Sewall-Menon et. al (2012), which ranged from an average per girl cost of $\$ 53$ to $\$ 704$. More work is needed to understand the cost and the cost-effectiveness of these interventions. 
To have the most positive impact on the lives of adolescent girls, investment should be directed toward empowerment interventions with multicomponent and multilevel designs, and longer duration.

Findings from Bangladesh (5, Burkina Faso 64, Ethiopia 6B, India 7 , Kenya (4, Liberia 8. and Tanzania 6C demonstrate the effectiveness of improving outcomes for girls by intervening at multiple levels (individual, household, and community). Multicomponent research designs - with additive arms such as those in Kenya (4), Liberia 8 , and Zambia 9-provide important evidence of the incremental effects of each study component. Interventions that are implemented on multiple levels coupled with a multi-arm evaluation could isolate the effects of different intervention components to better understand the pathway through which the intervention had its effects.

Over the past decade, there has been greater appreciation of the needs and opportunities of very young adolescents, resulting in more interventions being targeted toward this age group. The availability of more and better data has made their situation clearer. Given the long duration of adolescence (10 years) coupled with a confluence of physical, social, and cognitive changes, investment in this population needs to be long-term to understand how very young adolescents progress into adulthood. Over time, this will allow us to observe changes in schooling, marriage, sexual experience, health, economic, and violence outcomes. Therefore, prospective cohort studies are critical to understand the needs of adolescents as they progress through this period and the long-term effects of interventions. This way, resources can be better directed to intervening at the right time and in the right way with adolescents.

\section{Economic underpinnings of girls' lives should influence the design of health, education, violence reduction, and child marriage prevention interventions.}

These empowerment and asset-building interventions took place in LMICs. Findings from these evaluations suggest that the economic underpinnings of girls' lives influence individual and household decisionmaking and outcomes for girls across a number of sectors. Some of the interventions $\left(4 \mathbf{B}^{8} \mathbf{8}\right.$ presented in this brief were designed to respond to families' economic constraints through use of conditional cash and asset transfers. In Kenya 4 and Liberia 8 , the conditional transfers to households were combined with empowerment components. Empowerment alongside cash or asset transfers was found to be effective in delaying age at marriage, making safer sexual experiences, and had mixed results on schooling across sites. Intervention designs need to take into account household poverty and continue to identify culturally appropriate ways to address the vulnerabilities of girls. Additional research is needed on indicators of economic well-being for girls, as this information can inform the design of additional intervention approaches that address a host of outcomes for girls. 


\section{In delivering assets to adolescent girls, it is critical to understand the drivers of events for adolescents (e.g., school dropout and child marriage) and the pathways to effect change.}

The interventions presented in this brief focus on building girls' health, social, and economic assets. There are some common approaches to the design, delivery, and content of these interventions, such as safe spaces to combat social isolation and content on gender and power and economic empowerment developed for specific segments of girls. Despite these common features, each intervention was uniquely designed within the local context knowing that the pathways to asset-building and empowerment vary by setting. For example, in Kibera, Kenya $4 \mathrm{~A}$, the health, life skills, and nutrition curriculum were delivered by trained mentors, whereas in Wajir,

Kenya $4 \mathrm{~B}$, the health, life skills, and nutrition curriculum were delivered by mentors and were assisted by pre-recorded audio sessions to address wide variation in the capacity of mentors.

Knowing that the drivers of child marriage vary greatly around the world, the intervention in Bangladesh 5 was designed to consider the dominance of arranged marriages, dowry, concerns about the reputation and safety of daughters, and a strong sense of duty among parents to marry their daughters early. Therefore, the theory of change underpinning the intervention included strong community engagement across the intervention arms, rather than as its own arm, to elevate the status of girls in their communities as assets rather than liabilities.

The multi-country study to delay marriage 6 developed specific, culturally appropriate pathways to effect change with slight variations for each country. For example, the approach to social norms change differed between project countries. The community conversations approach had been used extensively in Ethiopia, whereby community members meet periodically with trained facilitators who take them through a systematic process of problem identification and problem-solving. This approach was used in Ethiopia and Burkina Faso, but in Tanzania the social norms change approach was geared toward community and religious leaders, who were trained to deliver key messages on the risks of child marriage at events they might host or attend. There is a need to balance finding effective approaches for scale-up with the need to continue to develop programs that are responsive to the local context. 


\section{OPEN QUESTIONS}

The nine evaluations presented in this brief provide a strong foundation of evidence of what does and does not work to improve outcomes for adolescent girls in a variety of settings. The findings have generated a new set of learning questions for researchers, policymakers, donors, and practitioners.

\section{How can effective empowerment programs be transferred to other settings and made accessible to a larger population in sustainable ways?}

Many evaluations featured in this brief tested multiple components to see what package of interventions was most effective in improving outcomes for adolescent girls. Strategic decisions need to be made about whether interventions can be replicated elsewhere, what components are most transferable, and how best to prepare for scaling the program, including considerations of fidelity, quality, cost, and sustainability. In Burkina Faso, evidence from $6 A$ on effectiveness of community dialogues for delaying marriage led to a replication in the Eastern region of the country. Likewise, in Ethiopia, a partially scaled up version of $6 \mathrm{~B}$ is being replicated in the remote Benishangul-Gumuz region.

\section{How can we best measure and address the quality and coverage of interventions as they are being implemented?}

Interventions implemented poorly or those with limited reach can undermine evaluation and misrepresent the impact of effective interventions. Capturing the quality and coverage of interventions as they are implemented provides critical information about the reliability of the research findings. It also provides an opportunity for program adaptation in real-time and improved chances of program success.

\section{How can monitoring approaches best capture these elements and what are the best practices in program monitoring and evaluation for adolescent-focused empowerment programs?}

If programs adapt and change as they are implemented how can changes be documented in a way that can be accounted for in analyses of impact? If programs use conditional cash transfers or other incentives to households or individuals that improve participation (Kenya (4), Liberia 8, and Zambia (3), what are the potential unintended consequences? How can they be captured consistently in evaluations? And how can they be monitored at scale? 


\section{What are the priority implementation science questions for adolescent girls' programs to address?}

There is a growing body of evidence on what does and does not work for adolescent girls, but to continue refining effective interventions requires additional implementation science studies. Program exposure-both duration and intensity-varied across the interventions featured in this brief. Analyzing the impact to program duration ratios from a comparative perspective across studies where possible may suggest optimal designs for future evaluations by adjusting the intensity and length of exposure. Another potential implementation science question is the relative effectiveness of different platforms for reaching girls; potentially assessing optimal program reach, program exposure by subpopulations (young/old; in-school/out) and how the platform influences community and stakeholder engagement and buy-in. Cost and cost-effectiveness can be further explored through implementation science. This brief presents costing information from more than half of the evaluations to date, and costing data for other evaluations may be analyzed in the future. It is important to continue analyzing the cost as well as cost-effectiveness of individual components of interventions to determine what can be replicated and scaled.

\section{When in the life trajectory is it optimal to intervene to achieve priority outcomes, and what do we gain by following adolescents for a longer period of time?}

Some of the interventions tested the effectiveness of approaches for younger versus older girls to help answer the question of when it is best to intervene in the life trajectory of an adolescent girl to improve her outcomes. Given the relatively young age range of the target populations for many of the featured interventions, it would be important to build a cohort of girls and observe changes in schooling, marriage, sexual experience, health, economic, and violence outcomes. For example, AGI-K in Kenya 4 has already yielded findings on what is effective for young girls immediately post-intervention. In 2019, AGI-K will have data on two years post-intervention and the statistical power to assess key adolescent transitions. As the cohort gets older, it will be interesting to see the effect of the intervention on long-term indicators such as marriage and pregnancy. This will provide information on whether there is an increase or diminution of effects observed at midline. Knowing what works in the longer term can direct resources to the most effective approaches, and we seek funding to follow girls in many of these interventions over the longer term. 


\section{FURTHER READING}

Amin, S., J. Ahmed, J. Saha, M. Hossain, and E. Haque. 2016. "Delaying child marriage through communitybased skills-development programs for girls: Results from a randomized controlled study in rural Bangladesh." Dhaka and New York: Population Council.

Amin, S., J.S. Saha, and J.A. Ahmed. 2018. "Skills-building programs to reduce child marriage in Bangladesh: A randomized controlled trial," Journal of Adolescent Health 63(3): 293-300.

Austrian, Karen, Erica Soler-Hampejsek, Paul C. Hewett, Natalie Jackson Hachonda, and Jere R. Behrman. 2018. “Adolescent Girls Empowerment Programme: Endline Technical Report." Lusaka: Population Council.

Austrian, K., Erica Soler-Hampejsek, Natalie Jackson Hachonda, and Paul C. Hewett. 2018. "Adolescent Girls Empowerment Program (AGEP): Financial Literacy and Savings-Two-Year Follow-Up." Policy Brief. Nairobi: Population Council.

Austrian, K., Erica Soler-Hampejsek, Natalie Jackson Hachonda, and Paul C. Hewett. 2018. "Adolescent Girls Empowerment Program (AGEP): Health." Policy Brief. Nairobi: Population Council.

Austrian, K., Erica Soler-Hampejsek, Natalie Jackson Hachonda, and Paul C. Hewett. 2018. "Adolescent Girls Empowerment Program (AGEP): Sexual and Gender-Based Violence." Policy Brief. Nairobi: Population Council.

Austrian, K., E. Soler-Hampejsek, J. Mumah, B. Kangwana, Y. Wado, B. Abuya, V. Shah, and J. Maluccio. 2018. "Adolescent Girls Initiative-Kenya: Midline Results Report." Nairobi: Population Council.

Azevedo, J.P., M. Favara, S.E. Haddock, L.F. Lopez-Calva, M. Müller, and E. Perova. 2012. “Teenage Pregnancy and Opportunities in Latin America and the Caribbean: On Teenage Fertility Decisions, Poverty and Economic Achievement." Working Paper. Washington, DC: The World Bank.

Chae, Sophia and Thoai D. Ngo. 2017. "The Global State of Evidence on Interventions to Prevent Child Marriage," GIRL Center Research Brief No. 1. New York: Population Council.

Erulkar, Annabel. 2014. "Building the Assets to Thrive: Addressing the HIV-related Vulnerabilities of Adolescent Girls in Ethiopia." New York: Population Council.

Erulkar, A. and G. Medhin. 2014. "Evaluation of Health and Education Impacts of a Girls' Safe Spaces Program in Addis Ababa, Ethiopia." Addis Ababa: Population Council.

Erulkar, A., G. Medhin, and E. Weissman. 2017. “The Impact and Cost of Child Marriage Prevention in Three African Settings." Addis Ababa and New York: Population Council.

Guttmacher Institute. 2016. "Adding It Up: Costs and Benefits of Meeting the Contraceptive Needs of Adolescents in Sub-Saharan Africa." Fact sheet. New York: Guttmacher Institute.

Haberland, Nicole A., Katharine J. McCarthy, and Martha Brady. 2018. "A systematic review of adolescent girl program implementation in low- and middle-income countries: Evidence gaps and insights," Journal of Adolescent Health 63: 18-31.

Haberland, Nicole A., Katharine J. McCarthy, and Martha Brady. 2018. "Insights and Evidence Gaps in GirlCentered Programming: A Systematic Review," GIRL Center Research Brief No. 3. New York: Population Council. 
Hallman, Kelly, Elizabeth Kelvin, Berk Ozler, Juliette Seban, Erica Kuhlik, Cooper Alton, Joseph Kamara, and Sarah Goodman. 2016. "Combining mentoring programs with cash transfers for adolescent girls in Liberia: Baseline report." Policy Research Working Paper, no. WPS 7797. Washington, DC: World Bank Group.

Hallman Kelly, Elizabeth Kelvin, Berk Ozler, Juliette Seban, Erica Kuhlik, Cooper Alton, Joseph Kamara, Sarah Goodman. 2016. “Girl Empower Liberia Intervention Baseline Survey Report.” Fact sheet. New York: Population Council.

Hewett, Paul C., Amanda L. Willig, Jean Digitale, Erica Soler-Hampejsek, Natalie Jackson Hachonda, Jere R. Behrman, and Karen Austrian. 2018. "Adolescent Girls Empowerment Program (AGEP): Nutrition." Policy Brief. Washington, DC: Population Council.

Jejeebhoy, S.J. and K.G. Santhya. 2017. “Enabling adolescent boys to adopt attitudes that espouse gender equality and oppose violence against women and girls: Evidence from rural Bihar." Policy Brief. New Delhi: Population Council.

Jejeebhoy, Shireen J. and K.G. Santhya. 2018. "Preventing violence against women and girls in Bihar: Challenges for implementation and evaluation," Reproductive Health Matters 26(52): 20-36.

McCarthy, Katharine, Martha Brady, and Kelly Hallman. 2016. "Investing When It Counts: Reviewing the Evidence and Charting a Course of Research and Action for Very Young adolescents." New York: Population Council.

Santhya, K.G and S.J. Jejeebhoy. 2017. "Empowering women and addressing marital violence through selfhelp groups: Evidence from rural Bihar." Policy Brief. New Delhi: Population Council.

Santhya, K.G. and S. J. Jejeebhoy. 2017. "Feasibility of screening and referring women experiencing marital violence by engaging frontline workers: Evidence from rural Bihar." Policy Brief. New Delhi: Population Council.

Santhya, K.G. and S.J. Jejeebhoy. 2017. "Reducing violence against women and girls in India: Lessons from the Do Kadam programme." Policy Brief. New Delhi: Population Council.

Santhya, K.G. and S.J. Jejeebhoy. 2017. "Training locally elected representatives to act as change agents to promote egalitarian gender norms: Lessons learned from the Do Kadam Barabari Ki Ore programme." Policy Brief. New Delhi: Population Council.

Sewall-Menon, Jessica, Judith Bruce, Karen Austrian, Raven Brown, Jennifer Catino, Alejandra Colom, Angel Del Valle, Habtamu Demele, Annabel Erulkar, Kelly Hallman, Eva Roca, and Nadia Zibani. 2012. “The cost of reaching the most disadvantaged girls: Programmatic evidence from Egypt, Ethiopia, Guatemala, Kenya, South Africa, and Uganda." New York: Population Council.

UNICEF. 2011. “The State of the World's Children 2011. Adolescence: An Age of Opportunity." New York: UNICEF.

Weissman, Eva. 2017. “Violence Against Women and Girls in India: Cost Study." Unpublished report.

Wodon, Q., C. Male, A. Nayihouba, A. Onagoruwa, A. Savadogo, A. Yedan, J. Edmeades, A. Kes, N. John, L. Murithi, M. Steinhaus, and S. Petroni. 2017. “Economic Impacts of Child Marriage: Global Synthesis Report." Washington, DC: The World Bank and International Center for Research on Women.

Zaveri, Heather, Theresa Schulte, and Adam Swinburn. 2017. "The Cost of Implementing Select EvidenceBased Programs that Prevent Teen Pregnancy: An Overview of Study Findings." Mathematica Policy Research and Department of Health and Human Services' Office of Adolescent Health. 
ANNEX: OVERVIEW OF INTERVENTIONS AND EVALUATIONS

\begin{tabular}{|c|c|c|c|c|c|c|c|c|c|c|c|c|c|c|c|}
\hline \multirow[b]{3}{*}{ Country } & \multirow{2}{*}{$\begin{array}{c}\text { Abriendo } \\
\text { Futuros } \\
1\end{array}$} & \multirow{2}{*}{$\begin{array}{c}\begin{array}{c}\text { Abriendo } \\
\text { Oportuni- } \\
\text { dades }\end{array} \\
2\end{array}$} & \multirow{2}{*}{$\begin{array}{c}\text { AGEP } \\
3\end{array}$} & \multicolumn{2}{|c|}{ AGI-K } & \multirow{2}{*}{$\begin{array}{l}\text { BALIKA } \\
5\end{array}$} & \multicolumn{3}{|c|}{$\begin{array}{l}\text { Building Evidence to } \\
\text { Delay Marriage }\end{array}$} & \multicolumn{4}{|c|}{ Do Kadam Barabari Ki Ore } & \multirow{2}{*}{$\begin{array}{l}\text { Girl Empower } \\
8\end{array}$} & \multirow{2}{*}{$\begin{array}{l}\text { GirlsRead! } \\
9\end{array}$} \\
\hline & & & & Kibera & Wajir & & & & & $\begin{array}{l}\text { Male youth } \\
\text { clubs }\end{array}$ & $\begin{array}{l}\text { Self-help } \\
\text { groups }\end{array}$ & $\begin{array}{l}\text { Locally } \\
\text { elected reps }\end{array}$ & $\begin{array}{l}\text { Frontline } \\
\text { workers }\end{array}$ & & \\
\hline & Mexico & Guatemala & Zambia & \multicolumn{2}{|c|}{ Kenya } & Bangladesh & $\begin{array}{l}\text { Burkina } \\
\text { Faso }\end{array}$ & Ethiopia & Tanzania & \multicolumn{4}{|c|}{ India } & Liberia & Zambia \\
\hline Location & $\begin{array}{l}\text { Yucatan, } \\
\text { Mexico } \\
\text { (rural) }\end{array}$ & $\begin{array}{l}\text { Solola } \\
\text { District, } \\
\text { Guatemala } \\
\text { (rural) }\end{array}$ & $\begin{array}{l}\text { Lusaka, Cop- } \\
\text { perbelt, Central, } \\
\text { and Northwest- } \\
\text { ern Provinces, } \\
\text { Zambia (rural } \\
\text { and urban) }\end{array}$ & $\begin{array}{l}\text { Kibera } \\
\text { informal } \\
\text { settle-- } \\
\text { ment, } \\
\text { Nairobi, } \\
\text { Kenya } \\
\text { (urban } \\
\text { informal) }\end{array}$ & $\begin{array}{l}\text { Wajir } \\
\text { County, } \\
\text { North- } \\
\text { eastern } \\
\text { Kenya } \\
\text { (rural) }\end{array}$ & $\begin{array}{l}\text { Khulna, } \\
\text { Satkhira, Narail, } \\
\text { Bangladesh } \\
\text { (rural) }\end{array}$ & $\begin{array}{l}\text { Cascades } \\
\text { region } \\
\text { (rural) }\end{array}$ & $\begin{array}{l}\text { Amhara } \\
\text { region } \\
\text { (rural) }\end{array}$ & $\begin{array}{l}\text { Tabora } \\
\text { region } \\
\text { (rural) }\end{array}$ & $\begin{array}{l}\text { Patna } \\
\text { District, } \\
\text { Bihar, India } \\
\text { (rural) }\end{array}$ & $\begin{array}{l}\text { Nawada } \\
\text { District, } \\
\text { Bihar, India } \\
\text { (rural) }\end{array}$ & $\begin{array}{l}\text { Patna } \\
\text { District, } \\
\text { Bihar, India } \\
\text { (rural) }\end{array}$ & $\begin{array}{l}\text { Patna District, } \\
\text { Bihar, India } \\
\text { (rural) }\end{array}$ & $\begin{array}{l}\text { Nimba County, } \\
\text { Liberia (rural) }\end{array}$ & $\begin{array}{l}\text { Lusaka and } \\
\text { Copperbelt (Ndola } \\
\text { and Chingola), } \\
\text { Zambia (rural and } \\
\text { urban) }\end{array}$ \\
\hline Partners & $\begin{array}{l}\text { Municipal } \\
\text { authorities }\end{array}$ & $\begin{array}{l}\text { UNIMER } \\
\text { Centro- } \\
\text { america }\end{array}$ & $\begin{array}{l}\text { YWCA Zambia, } \\
\text { National Savings } \\
\text { and Credit Bank } \\
\text { of Zambia, } \\
\text { Zambia Ministry } \\
\text { of Health }\end{array}$ & $\begin{array}{l}\text { African Po } \\
\text { and Health } \\
\text { Center, Ita } \\
\text { Internation } \\
\text { Children }\end{array}$ & $\begin{array}{l}\text { Relation } \\
\text { Research } \\
\text {, Plan } \\
\text { al, Save the }\end{array}$ & $\begin{array}{l}\text { Population } \\
\text { Services and } \\
\text { Training Center, } \\
\text { Center for } \\
\text { International } \\
\text { Development } \\
\text { Issues (CIDIN) } \\
\text { Radboud } \\
\text { University } \\
\text { Nijmegen, } \\
\text { mPower }\end{array}$ & $\begin{array}{l}\text { Asso- } \\
\text { ciation } \\
\text { Munyu } \\
\text { des } \\
\text { Femmes } \\
\text { de la } \\
\text { Comoé }\end{array}$ & $\begin{array}{l}\text { Ethiopia } \\
\text { Minis- } \\
\text { try of } \\
\text { Women, } \\
\text { Children } \\
\text { and } \\
\text { Youth; } \\
\text { Amhara } \\
\text { Regional } \\
\text { Bureau of } \\
\text { Women, } \\
\text { Children, } \\
\text { and Youth }\end{array}$ & $\begin{array}{l}\text { Tabora } \\
\text { Founda- } \\
\text { tion } \\
\text { Devel- } \\
\text { opment } \\
\text { Trust }\end{array}$ & \multicolumn{4}{|c|}{$\begin{array}{l}\text { Centre for Catalyzing Change (C3) and the London School } \\
\text { of Hygiene \& Tropical Medicine }\end{array}$} & $\begin{array}{l}\text { IRC, World Bank, } \\
\text { Innovations for } \\
\text { Poverty Action }\end{array}$ & $\begin{array}{l}\text { JSI, Worldreader, } \\
\text { FAWEZA }\end{array}$ \\
\hline Donor & $\begin{array}{l}\text { W.K. Kellogg } \\
\text { Foundation, } \\
\text { John D. and } \\
\text { Catherine T. } \\
\text { MacArthur } \\
\text { Foundation }\end{array}$ & $\begin{array}{l}\text { Nike } \\
\text { Foundation, } \\
\text { Inter- } \\
\text { american } \\
\text { Develop- } \\
\text { ment Bank }\end{array}$ & $\begin{array}{l}\text { UK Department } \\
\text { for International } \\
\text { Development }\end{array}$ & \multicolumn{2}{|c|}{$\begin{array}{l}\text { UK Department } \\
\text { for International } \\
\text { Development }\end{array}$} & $\begin{array}{l}\text { The Embassy of } \\
\text { the Kingdom of } \\
\text { the Netherlands }\end{array}$ & USAID & & & \multicolumn{4}{|c|}{ UK Department for International Development } & NoVo Foundation & $\begin{array}{l}\text { PEPFAR DREAMS } \\
\text { Innovation } \\
\text { Challenge }\end{array}$ \\
\hline $\begin{array}{l}\text { Target } \\
\text { popula- } \\
\text { tion }\end{array}$ & $\begin{array}{l}657 \\
\text { indigenous } \\
\text { girls, ages } \\
\text { 11-17 years }\end{array}$ & $\begin{array}{l}768 \\
\text { indigenous } \\
\text { girls in rural } \\
\text { communi- } \\
\text { ties, ages } \\
12-17\end{array}$ & $\begin{array}{l}11,000 \text { girls from } \\
\text { lower-income } \\
\text { backgrounds } \\
\text { and living with } \\
\text { multiple levels } \\
\text { of vulnerability } \\
\text { (e.g., physical } \\
\text { and social iso- } \\
\text { lation, without } \\
\text { parents, in } \\
\text { low-income } \\
\text { households, and } \\
\text { not attending } \\
\text { school), ages } \\
10-19\end{array}$ & $\begin{array}{l}6,000 \text { tota } \\
3,500 \text {, age } \\
\text { Kibera 2,5 } \\
11-15\end{array}$ & $\begin{array}{l}\text { girls: Wajir } \\
\text { 11-14; } \\
0, \text { ages }\end{array}$ & $\begin{array}{l}9,700 \text { girls, ages } \\
12-18\end{array}$ & \multicolumn{3}{|c|}{$\begin{array}{l}12,550 \text { unmarried girls (regis- } \\
\text { tered), ages } 12-17\end{array}$} & $\begin{array}{l}1,100 \text { boys } \\
\text { and young } \\
\text { men par- } \\
\text { ticipating } \\
\text { in youth } \\
\text { clubs, ages } \\
13-21\end{array}$ & $\begin{array}{l}4,100 \\
\text { people: } \\
\text { Married } \\
\text { women par- } \\
\text { ticipating } \\
\text { in self-help } \\
\text { groups } \\
\text { (SHG), ages } \\
18-49 ; \\
\text { husbands } \\
\text { of SHG } \\
\text { members; } \\
\text { other mar- } \\
\text { ried men } \\
\text { and women } \\
\text { from the } \\
\text { community }\end{array}$ & $\begin{array}{l}1,500 \text { locally } \\
\text { elected male } \\
\text { and female } \\
\text { representa- } \\
\text { tives; mar- } \\
\text { ried women } \\
\text { ages } 18-49 \\
\text { and married } \\
\text { men ages } \\
18-54\end{array}$ & $\begin{array}{l}\text { 1,100 com- } \\
\text { munity-based } \\
\text { frontline work- } \\
\text { ers (FLWs) } \\
\text { including: } \\
\text { Accredited } \\
\text { social health } \\
\text { activists, } \\
\text { auxiliary nurse } \\
\text { midwives, } \\
\text { and others } \\
\text { under the in- } \\
\text { tegrated child } \\
\text { development } \\
\text { schemes in } \\
9 \text { villages } \\
\text { within a } \\
\text { radius of 5-6 } \\
\text { kilometers of } \\
\text { one primary } \\
\text { health center }\end{array}$ & $\begin{array}{l}772 \text { rural girls, } \\
\text { ages } 13-14\end{array}$ & $\begin{array}{l}1,630 \text { grade } 7 \\
\text { girls attending } \\
36 \text { government } \\
\text { schools in select } \\
\text { districts }\end{array}$ \\
\hline
\end{tabular}


ANNEX: OVERVIEW OF INTERVENTIONS AND EVALUATIONS (continued)

\begin{tabular}{|c|c|c|c|c|c|c|c|c|c|c|c|c|c|c|}
\hline \multirow[b]{3}{*}{ Country } & \multirow{3}{*}{$\begin{array}{c}\text { Abriendo } \\
\text { Futuros } \\
1 \\
\text { Mexico }\end{array}$} & \multirow{3}{*}{$\begin{array}{c}\begin{array}{c}\text { Abriendo } \\
\text { Oportuni- } \\
\text { dades }\end{array} \\
2 \\
\text { Guatemala }\end{array}$} & \multirow{3}{*}{$\begin{array}{c}\text { AGEP } \\
3 \\
\text { Zambia }\end{array}$} & AGI-K & \multirow{2}{*}{ BALIKA } & \multicolumn{3}{|c|}{$\begin{array}{l}\text { Building Evidence to } \\
\text { Delay Marriage }\end{array}$} & \multicolumn{4}{|c|}{ Do Kadam Barabari Ki Ore } & \multirow{2}{*}{$\begin{array}{l}\text { Girl Empower } \\
8\end{array}$} & \multirow{2}{*}{$\begin{array}{c}\text { GirlsRead! } \\
9\end{array}$} \\
\hline & & & & Kibera & & & & & $\begin{array}{l}\text { Male youth } \\
\text { clubs }\end{array}$ & $\begin{array}{l}\text { Self-help } \\
\text { groups }\end{array}$ & $\begin{array}{l}\text { Locally } \\
\text { elected reps }\end{array}$ & $\begin{array}{l}\text { Frontline } \\
\text { workers }\end{array}$ & & \\
\hline & & & & Kenya & Bangladesh & $\begin{array}{l}\text { Burkina } \\
\text { Faso }\end{array}$ & Ethiopia & Tanzania & \multicolumn{4}{|c|}{ India } & Liberia & Zambia \\
\hline $\begin{array}{l}\text { Frequency } \\
\text { of meet- } \\
\text { ings and } \\
\text { program } \\
\text { duration }\end{array}$ & $\begin{array}{l}\text { Weekly/ } \\
22 \text { months }\end{array}$ & $\begin{array}{l}\text { Weekly/ } \\
1 \text { year }\end{array}$ & $\begin{array}{l}\text { Weekly/ } \\
2 \text { years }\end{array}$ & $\begin{array}{l}\text { Weekly/ } \\
2 \text { years }\end{array}$ & $\begin{array}{l}\text { Weekly/ } \\
18 \text { months }\end{array}$ & $\begin{array}{l}\text { Weekly/ } \\
27 \\
\text { months }\end{array}$ & $\begin{array}{l}\text { Weekly/ } \\
28 \\
\text { months }\end{array}$ & $\begin{array}{l}\text { Weekly/ } \\
28 \\
\text { months }\end{array}$ & $\begin{array}{l}\text { Weekly/ } \\
18 \text { months }\end{array}$ & $\begin{array}{l}\text { Every two } \\
\text { weeks for } \\
\text { SHG mem- } \\
\text { bers and } \\
\text { monthly for } \\
\text { husbands } \\
\text { over } 12 \\
\text { months }\end{array}$ & $\begin{array}{l}\text { Every two } \\
\text { weeks for } 7 \\
\text { months }\end{array}$ & 7 months & $\begin{array}{l}\text { Weekly for } 11 \\
\text { months with girls } \\
\text { and monthly for } \\
8 \text { months with } \\
\text { girl-designated } \\
\text { caregivers }\end{array}$ & $\begin{array}{l}\text { Weekly/ } \\
6 \text { months }\end{array}$ \\
\hline $\begin{array}{l}\text { Total } \\
\text { number of } \\
\text { sessions/ } \\
\text { hours }\end{array}$ & 70 sessions & 32 sessions & 104 sessions & 104 sessions & $\begin{array}{l}44 \text { hours of life } \\
\text { skills for all }+ \\
100 \text { arm-specif- } \\
\text { ic hours }\end{array}$ & \multicolumn{3}{|c|}{$\begin{array}{l}32 \text { total hours ( } 16 \text { sessions in } \\
\text { community conversations arm } \\
\text { that ran for } 2 \text { hours each) with } \\
\text { option for additional convenings by } \\
\text { subcommittees }\end{array}$} & $\begin{array}{l}42 \text { ses- } \\
\text { sions of } \\
2 \text { hours/ } \\
\text { week; } \\
36 \text { cricket } \\
\text { sessions }\end{array}$ & $\begin{array}{l}24 \text { gender- } \\
\text { transforma- } \\
\text { tive learning } \\
\text { sessions } \\
\text { for SHG } \\
\text { members } \\
\text { and } 12 \text { for } \\
\text { husbands } \\
\text { of SHG } \\
\text { members }\end{array}$ & $\begin{array}{l}\text { 3-day train- } \\
\text { ing workshop } \\
\text { followed by } \\
14 \text { training } \\
\text { sessions }\end{array}$ & $\begin{array}{l}\text { 3-day training } \\
\text { program } \\
\text { for FLWs } \\
\text { conducted by } \\
\text { project staff } \\
\text { and monthly } \\
\text { meetings with } \\
\text { project staff }\end{array}$ & 32 sessions & 19 sessions \\
\hline $\begin{array}{l}\text { Inter- } \\
\text { vention } \\
\text { level(s) }\end{array}$ & Individual & Individual & Individual & $\begin{array}{l}\text { Individual, household, } \\
\text { community }\end{array}$ & $\begin{array}{l}\text { Individual and } \\
\text { community }\end{array}$ & \multicolumn{3}{|c|}{ Individual, household, community } & \multicolumn{4}{|c|}{ Individual and community } & $\begin{array}{l}\text { Individual and } \\
\text { household }\end{array}$ & $\begin{array}{l}\text { Individual and } \\
\text { community }\end{array}$ \\
\hline $\begin{array}{l}\text { Inter- } \\
\text { vention } \\
\text { compo- } \\
\text { nents }\end{array}$ & $\begin{array}{l}\text { Empower- } \\
\text { ment pro- } \\
\text { gram with } \\
6 \text { modules } \\
\text { covering 12 } \\
\text { weeks each, } \\
\text { handicrafts, } \\
\text { optional } \\
\text { soccer pro- } \\
\text { gram in one } \\
\text { community } \\
\text { initiated by } \\
\text { girls. }\end{array}$ & $\begin{array}{l}\text { Discussions } \\
\text { and signing } \\
\text { of commu- } \\
\text { nity con- } \\
\text { tracts with } \\
\text { community } \\
\text { leaders to } \\
\text { facilitate } \\
\text { girls' use of } \\
\text { safe spac- } \\
\text { es; weekly } \\
\text { safe space } \\
\text { meetings } \\
\text { during } \\
\text { non-school } \\
\text { hours to } \\
\text { go through } \\
\text { curriculum. }\end{array}$ & $\begin{array}{l}\text { Safe space } \\
\text { groups with girls } \\
\text { ages } 10-14 \text { and } \\
15-19 \text {; health } \\
\text { vouchers for } \\
\text { a package of } \\
\text { general wellness } \\
\text { and sexual and } \\
\text { reproductive } \\
\text { health services } \\
\text { at partner public } \\
\text { and private } \\
\text { healthcare pro- } \\
\text { viders; savings } \\
\text { accounts with } \\
\text { very low mini- } \\
\text { mum opening } \\
\text { balances and no- } \\
\text { fee deposits and } \\
\text { withdrawals. }\end{array}$ & $\begin{array}{l}\text { Violence Prevention: } \\
\text { Community dialogues } \\
\text { and action plans. } \\
\text { Education: Conditional } \\
\text { cash transfer included } \\
\text { a bimonthly payment } \\
\text { to the household, } \\
\text { direct payment of a } \\
\text { portion of school fees, } \\
\text { and a schooling kit for } \\
\text { the girls (incentives, } \\
\text { conditioned on girls' } \\
\text { enrollment and regular } \\
\text { attendance at school). } \\
\text { Health: Girls group } \\
\text { meetings or safe } \\
\text { spaces facilitated by } \\
\text { a young woman from } \\
\text { the community. Wealth } \\
\text { creation: Financial } \\
\text { education within the } \\
\text { group meetings and } \\
\text { savings accounts in } \\
\text { the urban site and } \\
\text { home banks in the } \\
\text { rural site. }\end{array}$ & $\begin{array}{l}\text { Education: } \\
\text { Tutoring in } \\
\text { mathematics } \\
\text { and English } \\
\text { (in-school girls), } \\
\text { and computing } \\
\text { or financial } \\
\text { training (out- } \\
\text { of-school girls). } \\
\text { Gender rights } \\
\text { awareness } \\
\text { training: Life } \\
\text { skills training on } \\
\text { gender rights } \\
\text { and negotia- } \\
\text { tion, critical } \\
\text { thinking, and } \\
\text { decisionmaking. } \\
\text { Livelihoods } \\
\text { skills: Training } \\
\text { in computers, } \\
\text { entrepreneur- } \\
\text { ship, mobile } \\
\text { phone servicing, } \\
\text { photography, } \\
\text { and basic first } \\
\text { aid. }\end{array}$ & \multicolumn{3}{|c|}{$\begin{array}{l}\text { In each country: (1) Community di- } \\
\text { alogue to encourage social norms } \\
\text { change related to the practice of } \\
\text { child marriage. (2) Provision of } \\
\text { school materials to encourage } \\
\text { school attendance and thereby } \\
\text { discourage an early, arranged mar- } \\
\text { riage. (3) Provision of a conditional } \\
\text { asset transfer in the form of live- } \\
\text { stock (a goat in Burkina Faso and } \\
\text { Tanzania; chickens in Ethiopia), } \\
\text { provided on the condition that girls } \\
\text { remain unmarried and in school } \\
\text { during the pilot. }\end{array}$} & $\begin{array}{l}\text { Gender- } \\
\text { transfor- } \\
\text { mative life } \\
\text { skills and } \\
\text { cricket } \\
\text { sessions } \\
\text { delivered } \\
\text { by club } \\
\text { members } \\
\text { who were } \\
\text { selected as } \\
\text { peer men- } \\
\text { tors and } \\
\text { who had } \\
\text { undergone } \\
\text { several } \\
\text { training } \\
\text { sessions. }\end{array}$ & $\begin{array}{l}\text { Gender- } \\
\text { transforma- } \\
\text { tive group } \\
\text { learning } \\
\text { sessions. }\end{array}$ & $\begin{array}{l}\text { Training } \\
\text { sessions }\end{array}$ & $\begin{array}{l}\text { Training } \\
\text { sessions }\end{array}$ & $\begin{array}{l}\text { Girl Empower and } \\
\text { Girl Empower+ } \\
\text { (GE+): (1) Girl } \\
\text { Empower life } \\
\text { skills curriculum. } \\
\text { (2) Facilitated } \\
\text { by young female } \\
\text { mentors from } \\
\text { the community } \\
\text { in safe spaces. } \\
\text { (3) Caregiver } \\
\text { discussions, } \\
\text { facilitated by IRC } \\
\text { staff. (4) Uncon- } \\
\text { ditional savings } \\
\text { start-up for the } \\
\text { girls in cash box } \\
\text { (\$2/month } \times 9 \\
\text { months = \$18). } \\
\text { (5) Capacity- } \\
\text { building for } \\
\text { health and } \\
\text { psychosocial } \\
\text { providers. GE+ } \\
\text { only: a partici- } \\
\text { pation incentive } \\
\text { payment for the } \\
\text { girls' attendance } \\
\text { in the program } \\
\text { sessions, paid } \\
\text { to their parents } \\
\text { (conditional cash } \\
\text { transfer) ( } \$ 1.25 / \\
\text { session } \times 32 \text { ses- } \\
\text { sions = } \$ 40 \text { ). }\end{array}$ & $\begin{array}{l}\text { E-reader: Girls } \\
\text { used e-readers } \\
\text { in girls' groups } \\
\text { and received own } \\
\text { e-reader for the } \\
\text { year. Each e-reader } \\
\text { featured about 100 } \\
\text { books, many from } \\
\text { African authors, of } \\
\text { varying reading lev- } \\
\text { els and diverse con- } \\
\text { tent. Many of the } \\
\text { books on e-readers } \\
\text { reflect themes in } \\
\text { the empowerment } \\
\text { curriculum; safe } \\
\text { spaces: led by } \\
\text { female from school } \\
\text { or community; girls } \\
\text { empowerment } \\
\text { curriculum and } \\
\text { either study time } \\
\text { or e-reader time } \\
\text { depending on arm; } \\
\text { e-reader time is } \\
\text { spent reading and } \\
\text { discussing books } \\
\text { together. }\end{array}$ \\
\hline
\end{tabular}


ANNEX: OVERVIEW OF INTERVENTIONS AND EVALUATIONS (continued)

\begin{tabular}{|c|c|c|c|c|c|c|c|c|c|c|c|c|c|c|c|}
\hline & \multirow{2}{*}{$\begin{array}{l}\text { Abriendo } \\
\text { Futuros } \\
\text { (1) }\end{array}$} & \multirow{2}{*}{$\begin{array}{c}\text { Abriendo } \\
\text { Oportuni- } \\
\text { dades } \\
2\end{array}$} & \multirow{2}{*}{$\begin{array}{c}\text { AGEP } \\
3\end{array}$} & \multicolumn{2}{|c|}{ AGI-K } & \multirow{2}{*}{$\begin{array}{c}\text { BALIKA } \\
5\end{array}$} & \multicolumn{3}{|c|}{$\begin{array}{l}\text { Building Evidence to } \\
\text { Delay Marriage }\end{array}$} & \multicolumn{4}{|c|}{ Do Kadam Barabari Ki Ore } & \multirow{2}{*}{$\begin{array}{l}\text { Girl Empower } \\
8\end{array}$} & \multirow{2}{*}{ GirlsRead! } \\
\hline & & & & $\begin{array}{c}\text { (4A) } \\
\text { Kibera }\end{array}$ & $\frac{4 \mathrm{~B}}{\text { Wajir }}$ & & & & & $\begin{array}{l}\text { Male youth } \\
\text { clubs }\end{array}$ & $\begin{array}{l}\text { 7B } \\
\text { Self-help } \\
\text { groups }\end{array}$ & $\begin{array}{l}\text { Locally } \\
\text { elected reps }\end{array}$ & $\begin{array}{l}\text { Frontline } \\
\text { workers }\end{array}$ & & \\
\hline Country & Mexico & Guatemala & Zambia & \multicolumn{2}{|c|}{ Kenya } & Bangladesh & $\begin{array}{l}\text { Burkina } \\
\text { Faso }\end{array}$ & Ethiopia & Tanzania & \multicolumn{4}{|c|}{ India } & Liberia & Zambia \\
\hline $\begin{array}{l}\text { Descrip- } \\
\text { tion of } \\
\text { com- } \\
\text { munity } \\
\text { engage- } \\
\text { ment (if } \\
\text { applica- } \\
\text { ble) }\end{array}$ & $\begin{array}{l}\text { Individual- } \\
\text { level } \\
\text { program but } \\
\text { contracts } \\
\text { signed in } \\
\text { meet- } \\
\text { ings with } \\
\text { community } \\
\text { leaders to } \\
\text { grant girls' } \\
\text { access to } \\
\text { the space }\end{array}$ & $\begin{array}{l}\text { Individual- } \\
\text { level } \\
\text { program } \\
\text { but } \\
\text { contracts } \\
\text { signed in } \\
\text { meetings } \\
\text { with } \\
\text { community } \\
\text { leaders to } \\
\text { grant girls' } \\
\text { access to } \\
\text { the space }\end{array}$ & & $\begin{array}{l}\text { Communit } \\
\text { and action } \\
\text { developme } \\
\text { implement } \\
\text { violence p }\end{array}$ & $\begin{array}{l}\text { y dialogues } \\
\text { plan } \\
\text { nt and } \\
\text { ation in } \\
\text { evention }\end{array}$ & $\begin{array}{l}\text { Community } \\
\text { discussions led } \\
\text { by mentors en- } \\
\text { couraged local } \\
\text { government } \\
\text { represen- } \\
\text { tatives and } \\
\text { local leaders } \\
\text { in implemen- } \\
\text { tation process } \\
\text { and sensitized } \\
\text { community to } \\
\text { importance of } \\
\text { girls' education } \\
\text { and risk of mar- } \\
\text { rying girls early. } \\
\text { Community } \\
\text { engagement } \\
\text { focused on } \\
\text { discussion of } \\
\text { SRH and rights, } \\
\text { life skills, right } \\
\text { of a young } \\
\text { woman to live } \\
\text { a free life, and } \\
\text { right to consent } \\
\text { and have choice } \\
\text { with regard to } \\
\text { marriage, sex, } \\
\text { and childbirth. }\end{array}$ & $\begin{array}{l}\text { Adapted ver } \\
\text { the commur } \\
\text { versations a } \\
\text { community } \\
\text { meet period } \\
\text { trained facili } \\
\text { take them th } \\
\text { systematic } \\
\text { problem ide } \\
\text { and problem } \\
16-\text { week cur } \\
\text { for commun } \\
\text { includes edu } \\
\text { and action-o } \\
\text { sessions to } \\
\text { information } \\
\text { ative impact } \\
\text { marriage an } \\
\text { girls' educat } \\
\text { to facilitate } \\
\text { to develop th } \\
\text { strategies to } \\
\text { child marria }\end{array}$ & $\begin{array}{l}\text { sion of } \\
\text { nity con- } \\
\text { pproach; } \\
\text { members } \\
\text { lically with } \\
\text { itators who } \\
\text { hrough a } \\
\text { process of } \\
\text { ntification } \\
\text { n-solving. } \\
\text { riculum } \\
\text { ity groups } \\
\text { ucational } \\
\text { oriented } \\
\text { provide } \\
\text { on neg- } \\
\text { t of early } \\
\text { id value of } \\
\text { tion and } \\
\text { groups } \\
\text { heir own } \\
\text { baddress } \\
\text { ge. }\end{array}$ & $\begin{array}{l}\text { Commu- } \\
\text { nity and } \\
\text { religious } \\
\text { leaders } \\
\text { trained } \\
\text { to } \\
\text { deliver } \\
\text { key mes- } \\
\text { sages at } \\
\text { events } \\
\text { they } \\
\text { might } \\
\text { host or } \\
\text { attend }\end{array}$ & $\begin{array}{l}\text { Commu- } \\
\text { nity-wide } \\
\text { campaigns } \\
\text { conducted } \\
\text { by club } \\
\text { members }\end{array}$ & $\begin{array}{l}\text { Commu- } \\
\text { nity-wide } \\
\text { campaigns } \\
\text { conducted } \\
\text { by SHG } \\
\text { members } \\
\text { and hus- } \\
\text { bands }\end{array}$ & $\begin{array}{l}\text { For married } \\
\text { men and } \\
\text { women from } \\
\text { the com- } \\
\text { munity: } 14 \\
\text { sensitization } \\
\text { sessions on } \\
\text { gender, vio- } \\
\text { lence, and } \\
\text { alcohol- } \\
\text { abuse- } \\
\text { related } \\
\text { matters (one } \\
\text { session every } \\
2 \text { weeks), } \\
\text { and com- } \\
\text { munity--wide } \\
\text { campaigns } \\
\text { delivered } \\
\text { by locally } \\
\text { elected rep- } \\
\text { resentatives } \\
\text { with support } \\
\text { of a local } \\
\text { NGO. }\end{array}$ & $\begin{array}{l}\text { Community- } \\
\text { wide } \\
\text { campaigns }\end{array}$ & $\begin{array}{l}\text { One local service } \\
\text { provider in } \\
\text { each commu- } \\
\text { nity trained on } \\
\text { gender-based } \\
\text { violence (GBV) } \\
\text { core concepts, } \\
\text { psychological } \\
\text { first aid, and the } \\
\text { local GBV referral } \\
\text { pathway protocol } \\
\text { to support girls } \\
\text { who experience } \\
\text { GBV and other } \\
\text { forms of abuse. } \\
\text { Caregiver discus- } \\
\text { sion groups. }\end{array}$ & $\begin{array}{l}\text { Community en- } \\
\text { gagement directed } \\
\text { toward adults who } \\
\text { influence girls' } \\
\text { opportunities and } \\
\text { attitudes toward } \\
\text { education; home } \\
\text { visits for girls who } \\
\text { miss 2+ sessions; } \\
4 \text { training sessions } \\
\text { with parents, } \\
\text { parent teachers } \\
\text { association rep- } \\
\text { resentatives, and } \\
\text { school administra- } \\
\text { tors during each } \\
\text { program year. }\end{array}$ \\
\hline $\begin{array}{l}\text { Duration } \\
\text { between } \\
\text { end of } \\
\text { interven- } \\
\text { tion and } \\
\text { results } \\
\text { present- } \\
\text { ed }\end{array}$ & $\begin{array}{l}\text { Immediate } \\
\text { post- } \\
\text { intervention }\end{array}$ & 1 year & 2 years & $\begin{array}{l}\text { Immediate } \\
\text { vention (w } \\
\text { on 2 years } \\
\text { vention in }\end{array}$ & $\begin{array}{l}\text { post- inter- } \\
\text { I have data } \\
\text { post- inter- } \\
\text { 019) }\end{array}$ & $\begin{array}{l}\text { Immediate } \\
\text { post- } \\
\text { intervention }\end{array}$ & Immediate $\mathrm{p}$ & oost-interver & tion & 2 months & 4 months & $\begin{array}{l}\text { Immediate } \\
\text { post- } \\
\text { intervention }\end{array}$ & $\begin{array}{l}\text { Immediate } \\
\text { post- } \\
\text { intervention }\end{array}$ & 15 months & $\begin{array}{l}\text { Immediate post- } \\
\text { intervention and } \\
4-7 \text { months post- } \\
\text { intervention }\end{array}$ \\
\hline $\begin{array}{l}\text { Evalua- } \\
\text { tion de- } \\
\text { sign and } \\
\text { analysis }\end{array}$ & $\begin{array}{l}\text { Quasi-ex- } \\
\text { perimental/ } \\
\text { Treatment } \\
\text { on the } \\
\text { Treated }\end{array}$ & $\begin{array}{l}\text { RCT/Intent } \\
\text { to Treat }\end{array}$ & $\begin{array}{l}\text { RCT/Intent to } \\
\text { Treat as primary } \\
\text { analysis method } \\
\text { with secondary } \\
\text { analysis of } \\
\text { Treatment on } \\
\text { the Treated as } \\
\text { with two-staged } \\
\text { least squares } \\
\text { instrumentation }\end{array}$ & $\begin{array}{l}\text { RCT/ } \\
\text { Intent to } \\
\text { Treat as } \\
\text { primary } \\
\text { analysis } \\
\text { method } \\
\text { with sec- } \\
\text { ondary } \\
\text { analysis } \\
\text { of Treat- } \\
\text { ment } \\
\text { on the } \\
\text { Treated } \\
\text { as with } \\
\text { two- } \\
\text { staged } \\
\text { least } \\
\text { squares } \\
\text { instru- }\end{array}$ & $\begin{array}{l}\text { RCT/ } \\
\text { Intent to } \\
\text { Treat as } \\
\text { primary } \\
\text { analysis } \\
\text { method } \\
\text { with } \\
\text { secondary } \\
\text { analysis of } \\
\text { Treatment } \\
\text { on the } \\
\text { Treated as } \\
\text { with two- } \\
\text { staged } \\
\text { least } \\
\text { squares } \\
\text { instru- } \\
\text { mentation }\end{array}$ & $\begin{array}{l}\text { RCT/Intent to } \\
\text { Treat }\end{array}$ & $\begin{array}{l}\text { Quasi- } \\
\text { experi- } \\
\text { mental// } \\
\text { Treatment } \\
\text { on the } \\
\text { Treated } \\
\text { (Risk } \\
\text { ratio) }\end{array}$ & $\begin{array}{l}\text { Pre-post/ } \\
\text { Risk ratio }\end{array}$ & $\begin{array}{l}\text { Quasi- } \\
\text { experi- } \\
\text { mental/ } \\
\text { Treat- } \\
\text { ment } \\
\text { on the } \\
\text { Treated } \\
\text { (Risk } \\
\text { ratio) }\end{array}$ & $\begin{array}{l}\text { RCT/Intent } \\
\text { to Treat }\end{array}$ & $\begin{array}{l}\text { RCT/Intent } \\
\text { to Treat }\end{array}$ & $\begin{array}{l}\text { Quasi- } \\
\text { experi- } \\
\text { mental/ } \\
\text { Difference in } \\
\text { Differences }\end{array}$ & $\begin{array}{l}\text { Pre-test/post- } \\
\text { test }\end{array}$ & $\begin{array}{l}\text { RCT/Intent to } \\
\text { Treat }\end{array}$ & $\begin{array}{l}\text { RCT/Entropy } \\
\text { Balancing, Intent } \\
\text { to Treat, and } \\
\text { Treatment on the } \\
\text { Treated }\end{array}$ \\
\hline
\end{tabular}


ANNEX: OVERVIEW OF INTERVENTIONS AND EVALUATIONS (continued)

\begin{tabular}{|c|c|c|c|c|c|c|c|c|c|c|c|c|c|c|c|}
\hline \multirow[b]{3}{*}{ Country } & \multirow{3}{*}{$\begin{array}{c}\text { Abriendo } \\
\text { Futuros } \\
1 \\
\text { Mexico }\end{array}$} & \multirow{3}{*}{$\begin{array}{c}\begin{array}{c}\text { Abriendo } \\
\text { Oportuni- } \\
\text { dades }\end{array} \\
2 \\
\text { Guatemala }\end{array}$} & \multirow{3}{*}{$\begin{array}{l}\text { AGEP } \\
3 \\
\text { Zambia }\end{array}$} & \multicolumn{2}{|c|}{ AGI-K } & \multirow{2}{*}{$\begin{array}{l}\text { BALIKA } \\
5\end{array}$} & \multicolumn{3}{|c|}{$\begin{array}{l}\text { Building Evidence to } \\
\text { Delay Marriage }\end{array}$} & \multicolumn{4}{|c|}{ Do Kadam Barabari Ki Ore } & \multirow{2}{*}{$\begin{array}{c}\text { Girl Empower } \\
8\end{array}$} & \multirow{2}{*}{$\begin{array}{c}\text { GirlsRead! } \\
9\end{array}$} \\
\hline & & & & $\begin{array}{l}\text { 4A } \\
\text { Kibera }\end{array}$ & $\frac{4 B}{\text { Wajir }}$ & & (6A) & $6 B$ & (6C) & $\begin{array}{l}\text { MA } \\
\text { Male youth } \\
\text { clubs }\end{array}$ & $\begin{array}{c}\text { 7B } \\
\text { Self-help } \\
\text { groups }\end{array}$ & $\begin{array}{c}\text { 7C } \\
\text { Locally } \\
\text { elected reps }\end{array}$ & $\begin{array}{l}\text { 7D } \\
\text { Frontline } \\
\text { workers }\end{array}$ & & \\
\hline & & & & \multicolumn{2}{|c|}{ Kenya } & Bangladesh & $\begin{array}{c}\text { Burkina } \\
\text { Faso }\end{array}$ & Ethiopia & Tanzania & \multicolumn{4}{|c|}{ India } & Liberia & Zambia \\
\hline $\begin{array}{l}\text { Sample } \\
\text { size }\end{array}$ & 417 & 1,148 & 5,242 & 2,394 & 2,150 & 11,609 & 2,500 & 2,500 & 2,500 & 1,149 & $\begin{array}{l}1,614 \text { SHG } \\
\text { mem- } \\
\text { bers, } 550 \\
\text { husbands } \\
\text { of SHG, and } \\
1,937 \text { other } \\
\text { community } \\
\text { women who } \\
\text { were not } \\
\text { members of } \\
\text { SHGs }\end{array}$ & $\begin{array}{l}\sim 1,500 \text { men } \\
\text { and women }\end{array}$ & 1,081 & 1,216 girls & 1,299 \\
\hline $\begin{array}{l}\text { Study } \\
\text { arms and } \\
\text { clusters } \\
\text { per arm } \\
\text { (if appli- } \\
\text { cable) }\end{array}$ & $\begin{array}{l}8 \text { inter- } \\
\text { vention } \\
\text { commu- } \\
\text { nities and } \\
3 \text { control } \\
\text { communi- } \\
\text { ties }\end{array}$ & $\begin{array}{l}20 \text { treat- } \\
\text { ment clus- } \\
\text { ters and } \\
20 \text { control } \\
\text { clusters }\end{array}$ & $\begin{array}{l}\text { Safe spaces ( } 40 \\
\text { clusters); safe } \\
\text { spaces + health } \\
\text { voucher (40 } \\
\text { clusters); safe } \\
\text { spaces + health } \\
\text { voucher+ sav- } \\
\text { ings account (40 } \\
\text { clusters); control } \\
\text { ( } 60 \text { clusters: } 40 \\
\text { internal control } \\
\text { clusters and } 20 \\
\text { external control } \\
\text { clusters [urban } \\
\text { areas only]) }\end{array}$ & $\begin{array}{l}\text { Violence } \\
\text { violence } \\
\text { violence } \\
\text { + health; } \\
\text { educatiol } \\
\text { wealth cr } \\
\text { ly } 20 \text { clus } \\
\text { Wajir and } \\
\text { girls/arm }\end{array}$ & $\begin{array}{l}\text { evention; } \\
\text { education; } \\
\text { education } \\
\text { olence + } \\
\text { + health + } \\
\text { ation; rough- } \\
\text { rs/arm in } \\
\text { oughly } 600 \\
\text { n Kibera }\end{array}$ & $\begin{array}{l}\text { Education (24 } \\
\text { clusters); gen- } \\
\text { der awareness } \\
\text { (24 clusters); } \\
\text { Illelihoods } \\
\text { (24 clusters); } \\
\text { control (24 } \\
\text { clusters) }\end{array}$ & \multicolumn{3}{|c|}{$\begin{array}{l}500 \text { girls in each arm: Community } \\
\text { dialogue, provision of school ma- } \\
\text { terials, provision of asset transfer } \\
\text { conditional on staying in school } \\
\text { and unmarried; all three approach- } \\
\text { es combined; control }\end{array}$} & $\begin{array}{l}15 \text { inter- } \\
\text { vention } \\
\text { and control } \\
\text { communi- } \\
\text { ties }\end{array}$ & $\begin{array}{l}3 \text { arms. } \\
\text { (1) SHG } \\
\text { members, } \\
\text { (2) } \mathrm{SHG} \\
\text { members+ } \\
\text { their } \\
\text { husbands, } \\
\text { (3) Control. } \\
\text { 14 villages } \\
\text { per arm } \\
\text { (42 villages } \\
\text { total) }\end{array}$ & $\begin{array}{l}2 \text { village } \\
\text { councils } \\
\text { containing } 9 \\
\text { villages for } \\
\text { intervention } \\
\text { and } 2 \text { village } \\
\text { councils as } \\
\text { compar- } \\
\text { ison area } \\
\text { containing } 13 \\
\text { villages }\end{array}$ & $\begin{array}{l}\text { Baseline and } \\
\text { endline panel } \\
\text { surveys with } \\
\text { women up to } \\
\text { age } 39 \text { who } \\
\text { were pregnant } \\
\text { or had } \\
\text { children ages } \\
0-5 \text { given } \\
\text { elevated risk } \\
\text { of marital } \\
\text { violence }\end{array}$ & $\begin{array}{l}3 \text { arms. (1) Girl } \\
\text { Empower, (2) Girl } \\
\text { Empower + cash, } \\
\text { (3) Control. } \\
28 \text { villages per } \\
\text { arm (84 villages } \\
\text { total) }\end{array}$ & $\begin{array}{l}3 \text { arms. (1) Safe } \\
\text { spaces + e-reader } \\
+ \text { community en- } \\
\text { gagement, (2) safe } \\
\text { spaces + communi- } \\
\text { ty engagement, } \\
\text { (3) Control. } \\
36 \text { schools and } \\
12 \text { schools/arm } \\
\text { ( } 32 \text { students/ } \\
\text { school) }\end{array}$ \\
\hline $\begin{array}{l}\text { Primary } \\
\text { out- } \\
\text { come(s) } \\
\text { measured }\end{array}$ & $\begin{array}{l}\text { Pregnancy, } \\
\text { sexual and } \\
\text { reproduc- } \\
\text { tive health } \\
\text { knowledge, } \\
\text { financial } \\
\text { literacy, and } \\
\text { school } \\
\text { enrollment }\end{array}$ & $\begin{array}{l}\text { School } \\
\text { enrollment, } \\
\text { ever mar- } \\
\text { ried, and } \\
\text { experience } \\
\text { of violence }\end{array}$ & $\begin{array}{l}\text { Marriage, sexu- } \\
\text { ally transmitted } \\
\text { infections } \\
\text { including HIV, } \\
\text { unintended } \\
\text { pregnancy }\end{array}$ & $\begin{array}{l}\text { Build girl- } \\
\text { educatiol } \\
\text { and econ } \\
\text { as well as } \\
\text { househol } \\
\text { assets in } \\
\text { term, whi } \\
\text { delayed o } \\
\text { in the lon }\end{array}$ & $\begin{array}{l}\text { vel social, } \\
\text { health, } \\
\text { mic assets, } \\
\text { mprove } \\
\text { economic } \\
\text { ne medium } \\
\text { n will lead to } \\
\text { ild-bearing } \\
\text { er term }\end{array}$ & $\begin{array}{l}\text { Percentage of } \\
\text { girls remaining } \\
\text { unmarried } \\
\text { below age } 18\end{array}$ & \multicolumn{3}{|c|}{$\begin{array}{l}\text { Ever married and in school in } \\
\text { current or previous year }\end{array}$} & $\begin{array}{l}\text { Gender } \\
\text { roles and } \\
\text { notions of } \\
\text { mascu- } \\
\text { linity, per- } \\
\text { ceptions } \\
\text { about peer } \\
\text { reactions } \\
\text { to boys } \\
\text { acting in } \\
\text { gender- } \\
\text { equitable } \\
\text { ways, } \\
\text { men's } \\
\text { controlling } \\
\text { behaviors, } \\
\text { and the ac- } \\
\text { ceptability } \\
\text { of violence } \\
\text { against } \\
\text { women } \\
\text { and girls }\end{array}$ & $\begin{array}{l}\text { Gender-role } \\
\text { attitudes, } \\
\text { perpetra- } \\
\text { tion and } \\
\text { experience } \\
\text { of physical, } \\
\text { emotional, } \\
\text { or sexual } \\
\text { violence }\end{array}$ & $\begin{array}{l}\text { Gender-role } \\
\text { attitudes and } \\
\text { attitudes } \\
\text { about the } \\
\text { acceptability } \\
\text { of violence } \\
\text { against wom- } \\
\text { en, men's } \\
\text { abuse of } \\
\text { alcohol and } \\
\text { displays of } \\
\text { drunkenness, } \\
\text { egalitarian } \\
\text { marital } \\
\text { relations, and } \\
\text { intervention } \\
\text { in cases of } \\
\text { violence } \\
\text { against } \\
\text { women and } \\
\text { girls }\end{array}$ & $\begin{array}{l}\text { Interaction } \\
\text { with FLW } \\
\text { on marital } \\
\text { violence, } \\
\text { help-seeking, } \\
\text { disclosure } \\
\text { of violence } \\
\text { at time of } \\
\text { screening }\end{array}$ & Sexual violence & $\begin{array}{l}\text { Literacy among } \\
\text { girls attending } \\
\text { grade } 7 \text { at govern- } \\
\text { ment schools }\end{array}$ \\
\hline
\end{tabular}




\section{GIRL Center}

FOR INNOVATION, RESEARCH, AND LEARNING

The Girl Innovation, Research, and Learning (GIRL) Center generates, synthesizes, and translates evidence to transform the lives of adolescent girls

popcouncil.org/girlcenter 